Nachev, D.A. (2020) Multi-faceted creativity of artists of one city. Current issues of cultural heritage in 2020. Collection of Scientific Articles. European Scientific e-Journal, 1 (1), 24-46. Hlučín-Bobrovníky: "Anisiia Tomanek" OSVČ.

DOI: $10.47451 /$ art2020-08-001

EOI: $10.11244 /$ art2020-08-001

The paper is published in Crossref, Internet Archive, Google Scholar, Academic Resource Index ResearchBib, JGate, ISI, CiteFactor, ICI, eLibrary databases.

Dmitry A. Nachev

Member of The St Petersburg Union of Artists of Russia

Member of the Association of Art Historians (AIS)

Member of the International Union of Teachers and Artists

Senior Lecturer

St Petersburg Institute of Art and Restoration

International School of Design

St Petersburg, Russia

E-mail: 3izo2@mail.ru

\title{
Multi-faceted creativity of artists of one city
}

\section{Abstract:}

The study of the topic provides an opportunity to get acquainted with another important phenomenon in Russian art, which received the concept of severe style and developed in the 1960s. The research considers the evolution and development of the genres of still life and landscape, their interpenetration in the works of artists. It also considers the diversity of creativity, different artists united by one city. Special attention is paid to the work of Leningrad artists. The artists of the Leningrad school of painting, characterized by certainty professional and moral criteria and as a result, caution against innovations. The study analyzes the creativity of such artists as A. Yakovlev, Y. Krestovsky, E. Moiseenko, O. Khorosheva, A. Lytkin, and others.

\section{Keywords:}

art, painting, painter, still life, landscape, artists of the Leningrad school of painting, A. Yakovlev, Y. Krestovsky, E. Moiseenko, O. Khorosheva, A. Lytkin.

\section{Introduction.}

'View from the Window' in the works of the artists Y.I. Krestovsky, E.E. Moiseenko and A.A. Yakovlev

You can consider the work of Leningrad (St Petersburg) masters Y.I. Krestovsky and A.A. Yakovlev with the involvement of other artists whose works touched the theme of 'view from the window'.

The study of the topic provides an opportunity to get acquainted with another important phenomenon in Russian art, which received the concept of severe style and 
developed in the 1960s. In itself, this concept is very conditional and it is a kind of metaphor. For the first time, the term of severe style was used by the critic A.A. Kamensky first in oral speech, and then a group of artists who worked in the late 1950s and early 1960s, mainly Muscovites, which included N.I. Andronov, G.M. Korzhev, V.I. Ivanov, V.E. Popkov, P.P. Ossovsky, T.T. Salakhov, the Smolin brothers, D.D. Zhilinsky, i.e., most of the leading artists of the 1960s, was designated under this concept. Leningrad artists E.E. Moiseenko, I.Y. Krestovsky, A.A. Yakovlev belonged to the group, too.

The artists, conditionally united in this group, created works, in which most important feature of the figurative structure was metaphorical. Of course, this concept itself is characteristic of traditional and realistic art works. However, these masters used mainly the plot and semantic nature of the metaphor, referring mainly to its pictorial and plastic essence.

This is not difficult to trace in the works of Y.I. Krestovsky. As a master of still-life, he understands the meaning of the subject more than its realistic essence. In his still-lifes, the subject acts as a symbol and expands the idea of the content of the paintings. Maybe that is why he turns to the theme of open window that carries a romantic charge. If you recall some aspects of the development of European art, you can remember the deep spatial window-niche that has fascinated artists since the 15th century. It was there, in the depths, that the big world, which artists gravitated to but they did not have a tradition of displaying it, was developing.

Another surge of attention to the motif of the window, opened out of interest in the entire outside world, is used by romantic artists of the early 19th century. However, now outside the window, there was the world of the infinite. We often do not even see, but only realize, imagine, do it through the look outside of the hero of the picture. Romantics like to contrast the small, ordinary, and real world, which can be seen and felt, with the big world, which leads both the eye and the imagination to infinity.

This is the approach to the genre that Yaroslav Krestovsky has in his works of the second half of the 1960s. This is Cage with Parrots (1965), White Night. Bouquet of Lilac (1967), Still-Life with an Aquarium (1968) and pencil Still-Life with a Mirror (1967). White Night. Bouquet of Lilac contains more elements of the real world. The lyrical theme of the connection and continuity of different cultural epochs is traced in it. The world was still in the pale, silvery-pearly haze of the white night. The artist elaborated on the characteristics of the interior. We see details of the furniture, antique furniture, a clock on the wall, and a luxurious bouquet of lilacs in a round vase. 
The most characteristic compositional technique of the 1960s was the use of a narrow strip of the first plan (window sill) to write the actual still life, but the middle and far plans were occupied by the landscape. The artist deliberately emphasizes this foreground and the plane of the canvas.

The motif of the city is familiar to us from other still-lifes with a window by Yaroslav Krestovsky. This is a house with a tower topped by dome's onion and a weather vane, empire mansions and tenements known from other works. They only move slightly in space in each new picture.

By a simple comparison of the small world of reality surrounding a person, and the ever-living craving for dreams, beauty and perfection, the artist speaks of philosophical problems, the essence of which lies in the perception of the world as eternal beauty.

Yaroslav Krestovsky composed his compositions. First of all, this applies to his still-lifes - complex, metaphorical, allowing to give greater semantic depth to the work, but the significance of the landscape motif is not implored by the artist. The master created his best works in the 1960s and 1970s. An interest to the theme of view from the window was realised by E.E. Moiseenko (Still-Life on the Windowsill; Winter (Birch) (1971), Window (1975), Blue Morning (1974), Son (1968), Young Artist (1970)) and A.A. Yakovlev (polyptych Our Pavshino. The Seasons of the Year (2011) and Bad Weather (2011)). Their works, created in the following decades, clearly demonstrate the evolution and development of a complex work that combines different genres of painting.

\section{Creativity of artists of the Leningrad school of painting}

The artists of the Leningrad school of painting, characterized by certainty professional and moral criteria and as a result, caution against innovations... [5], strict adherence to the traditions of the academic school, since the late 1950s, start looking toward the enrichment of scenic beauty, enhance the decorative and impressionistic survey in the themes, which does not aspire to comprehensive coverage of the phenomena. The search for new methods to enhance expressiveness leads to the appearance of an original genre, in which the expressive possibilities of still life and landscape, and sometimes the interior genre, clearly converge. Although still-life physically or spiritually prevails on the canvases, which is reflected in the names of paintings, it is obvious that it is inextricably, justifiably and necessary connection with the landscape, without which reflections on the eternity of the universe, the impermanence of human existence, as well as the transfer of the artist's personal experience would hardly be possible. 
Artistic problems and ways of interpenetrating of still-life and landscape were solved by brush masters in different ways. This could be due to unifying daylight (T. Afonina, V. Teterin, E. Antipova, B. Shamanov, N. Pozdneev), transmitting the state of the air environment and reflecting it on objects (B. Shamanov, Asters), focusing on the bright decorative nature of things and transmitting the form and texture due to color (S. Osipov), etc. Motif of a window or door, open or closed, often introduce thereby establishing a harmonious connection between the microcosm and the macrocosm (A. Yakovlev, Y. Krestovsky, B. Shamanov, E. Moiseenko). Introduction to the plot of the lyric hero (E. Moiseenko) serves as an indisputable method of enhancing personal emotional experience and philosophical understanding of the world.

Taisia Afonina's Still-Life with Willows (1964) is joyous and wordy. There are a lot of items made of different materials-glass, porcelain, metal, light fabric, the texture of which is revealed by daylight. This light falls on objects and differently plays on their surfaces, revealing all their beauty. It should be noted that the landscape in the picture is not as such, it is hidden behind a curtain and appears to us in the form of a stream of bright spring sunlight, which is a powerful unifying stilllife and landscape, guess the window. In this still-life, the artist frankly sets a coloristic task subtly developing the white and silver-gray scale that dominates the picture, and only emphasizes its beauty by the delicate introduction of cobalt, gold and yellowish-brownish shades.

Boris Shamanov also solved similar artistic problems in his work. Frankly putting a still-life in the landscape, he made bright or dim sunlight by the hero of the paintings. Jug with yellow flowers in the still-life of September. Yellow Flowers (1991) stands on the edge of a plank table. The stream of the brightest light plays on yellow large flowers and smaller orange nasturtiums transforming them and making them even more bright and sunny. The contrasting shadows, cast by the jug and the trees (the latter are not visible to the viewer, but are implied by the effect of introducing shadows), clearly indicate how the light is bright and strong. The landscape, given large broad strokes and circular lines and transmitting hilly terrain, ends with a circular horizon, which gives it an almost universal scale. Against this background, a giant bouquet that does not fit into the frame of the canvas, also carries the idea of the greatness of the great bouquet and, thus, gives a complete image of the world harmony. This harmony is also emphasized by the development of a noble color scheme of yellowish and bluish colors.

Universal scale is also given to the bouquet in the painting of Brier after the Rain (1989), the entire composition of which is built on the circular lines - the 
table, the vase, the bouquet and the rainbow. The bouquet is soaring over the landscape illuminating the landscape with its glow with a river and unsightly wooden huts. Juicy crimson tones, combined with azure-blue and emerald-green ones, give the canvas a fabulous color. The momentary beauty of the world is highlighted by a few fallen petals and leaves of rosehip on a wet table and a gradually dissolving rainbow.

Asters (2001) are different in mood. Snatched from a large landscape fragment with flowers in a simple glass jar makes it clear to the viewer that the landscape continues beyond the fragment. The general state of nature evokes a slight sadness for the past summer. The soft diffused light falling on the yellowing large leaves, on the asters already lowering their heads, on the white crumpled tablecloth (transmitting its glow to the Astras and making them glow from the inside as well), unites the still-life and the landscape with the general state of departure of years' joy. The artist seems to offer us to admire the colors of the coming autumn, carefully developing a green-brown and refined amethyst-lilac range, thus, setting and solving a decorative task.

The introduction of the window motif is found in many of Shamanov's paintings of the 1960s: Still-Life with an Alarm Clock (1962), Sprouted Potatoes (1966), Night. Candle at the Window (1969), etc. Undevelopment of the landscape in depth, bringing large objects and things, which partially obscure the world outside the window, to the foreground, the artist's view of what is depicted slightly from above, and often the combination of different points of view give Boris Shamanov's still-lifes monumentality and spiritual meaning.

The works of Yevgenia Antipova and Viktor Teterin give an idea of the great decorative possibilities and impressionistic tendencies of painting by Leningrad masters of the second half of the 19th century.

Noon (1982), Blooming Willow, Calla Lilies and Daffodils (1984), Apple Tree in Bloom (1997) and many other works of Yevgenia Antipova are written during plein air and are very harmonious, accurately set still-lifes, usually vases and other vessels with flowers, fruits, vegetables, food, arranged on small round tables in the garden under the trees. It often seems that the nature around obscures the still-life invading its life: branches of trees, bent and even lying on the table, endless glare, cast by objects on each other, all united by a bright sunny color... The circular forms of bouquets and tree branches, round tables, round horizon lines and fragmentary nature of many compositions, despite the lightness and cheerfulness of the canvases, give them a significant degree of monumentality. 
The window motif in E. Antipova's early work Books on the Table (1963) and the light of a winter sunset, pouring out of it, serve as a unifying beginning of the major mood of the workshop corner, achieved by developing a warm ochre scale with the introduction of noble red spots, and the winter embankment outside the window, with houses illuminated by pinkish light.

Color in Teterin's works plays a primary role. This is a contrasting painting made with temperamental large strokes. Still-Life with Braided Bottle (1969), Still life with Flowers (1964), Autumn Still-Life (1964-1972), Flowers under a Tree (1980), Blossoming Almond Trees on the Shores of the Black Sea (1981), Still-Life with Alpine Roses and the Vase (1983) and many other works are no different by a great variety in the choice of subject, but these flowers, fruits, vegetables, and dishes, made on the open air and the bright sun and written by juicy brush, convey harmony and complete unity of landscape and still life lines.

Nikolai Pozdneev's Still-Life in the Grass (1964) was painted in bright and juicy colors. Broad writing, powerful brushstroke, bodywork of paint, bright decorativeness is inherent in this work. The plot depicts everyday things, simple dishes and food lying on a napkin in the grass. There is no landscape as such, but it is certainly discernible, that is, a large field of green grass with yellow dandelions. The fragmentation of the composition, the circular shapes of objects, the bending blades of grass, the white napkin as a symbol of light and purity poetize the everyday motif, making it a part of the Universe.

A different, more graphic style of painting is typical for such masters of the Leningrad school as Evsei Moiseenko, Yaroslav Krestovsky, and Sergei Osipov.

Sergei Osipov's Autumn Branch (1974) and Bouquet of Cornflowers (1976) practically eliminate the problem of light and solves decorative problems using color, which creates the shape of objects and transmits their texture. In both works, the window motif is introduced, behind which a color spot in the form of an autumn yellow tree, as in Autumn Branch, or a grayish-bluish landscape, as in Bouquet of Cornflowers, necessarily echoes the colors of the object world. So, we can see achievment of the harmony and interpenetration of genres.

Yaroslav Krestovsky is a master admiring the subject. Whether it is a giant axe in Still-Life with an Axe (1965), placed among other ringing stabbing and cutting objects against the background of a frosted window, behind which snow-covered huts... or antique world, located on a table made of Karelian birch, with a huge antique clock and exquisite dolls in Clock and Dolls (1972) ... or a fantastic water world in Still-Life with an Aquarium (1968), set on a large window, behind which and through which you can see the roofs of the old city. In all cases, the still-life is 
placed in a temporal and spatial context. There is no conflict of opposition. These are still-lifes of landscapes and interiors at the same time (as in Clocks and Dolls), which change not only consistently, but often in places. So, the industrial landscape outside the window framed by heavy curtains looks like a picture of the outside world hanging on the wall. These are performances with a curtain (Still-Life with an Aquarium), and the theater set of White Night. Bonquet of Lilac (1967), and the transfer of one era to another through admiring both. It seems that developing the theme of the interpenetration of epochs by combining genres, Krestovsky did not overcome the literary and could not rise to the heights of miriskusniki in his work.

Evsei Moiseenko's still-lifes are full of moods and personal experiences. His usually nervous lines are calmed in still-life and landscape. If a still-life is painted with the introduction of a window, it is usually located at the window directly, close to it, or on the windowsill itself. In Still-Life with Tatarnik (1978), vertical lines (plant stems, fence, window frames) predominate. The rhythms of the stems and petals of plants create a sense of movement, dance, exultation. Heavy window frames enhance the movement, as if pushing the still-life out into the street and inviting the viewer to sit under a tree by the fence or run along a circular path that goes off to the left into the distance. The interpenetration of the still-life and landscape creates a mood of serene summer happiness. The joy of the flower dance is complemented by the joy of the kaleidoscopically devoted world outside the window (the landscape consists of fragments, and when the window glass swings, a different fragment is reflected in it). The background of the picture is filled with light, the front is linear. And you can clearly feel the presence of a person who is not visible, but who came, put the flowers (their trophies) in whatever they had to, so as not to wilt, and ran away, because the diagonals of the windows pushed him into the summer, joyful world. And we know how he will run along this circular path into the distance, towards happiness.

In Autumn Still-Life (1982), the main character of the work is shown in closeup. The view of peaceful country life serves to solve pictorial problems. The scent of the composition - a bowl with apples - is underlined and colored, this is the lightest spot in the whole picture is full of circular shapes. Other parts of the picture are filled with complex rhythmic lines. The landscape sets the mood for the still-life, and it takes on a plot: country house, autumn, a little sad (blackened trunks, fence, gate) ... The table divides two compositional plans - the first is subject, "talking" about the life of people, and the second, complicated by the perspective and depth given by a purely pictorial technique, speaks about the life of nature. Orange and greenish shades of objects and foliage bring a note of joy to the 
dark verticality of trunks and fences giving a sense of admiration for life with its changing seasons, each of which carries its own suburban joys. In other words, it is still-life and mood, still-life and feeling, but mood and feeling arise from a deep mutual penetration of nature and the world of objects.

In Portrait of a Boy (1962), Young Artist (1970), Boy under an Apple Tree (1980), the portraits of a teenager are placed, which are either in the walls of their room by the window, or in the garden under an apple tree. The boy is waiting for his future, he is protected while the world of his house or garden (Portrait of a Boy, Boy under an Apple Tree), or, conversely, is pushed by the window frames into the romance of life outside the window, with goats rushing like horses (Young Artist). The boy belongs both to the world in the room or garden, and at the same time, by his detachment or an unexpected thoughtfulness, or enthusiasm for age, to that other world, outside the window or outside the fence. Thus, the artist solves complex philosophical and ideological problems by introducing a lyric hero.

The philosophical understanding of still-life is also characteristic of the works of Andrey Yakovlev. In the painting Memory of Fallen Artists (1970), a red irezida in a pot is placed on the sill of an open window, behind which there is no landscape, and the space is decided in the form of a gray tone stretch and resembles a granite slab. Against this background, a flower with red petals that resemble many hearts in color and shape, looks like a symbol of memory. Strict verticals of stems, brushes, and window frames give the canvas a lofty solemnity, and a noble combination of red and gray do restrained luxury.

The theme of the window always played in the artist's significant role, both in early works (Letter from Leningrad, The Day Begins (both 1977), Rosemary (1980)), where the window or its fragment serves as a background for expressive still-life only and later (Cornflowers (1990), Tunguska (1991), Winter Bonquet (2008), The Day of Apple Feast of the Saviour (2007), Honey August and Berries of the Forest (both 2009), in which bright sunshine, the light which illuminate the entire interior space and unites the two worlds, outer and inner, the power of love for the beauty of the world, is raging at the open windows.

The polyptych of Our Pavshino. Seasons (2011), painted at the end of the master's life, brings the theme of the beauty of the world and personal experience to perfection. There are captivating April with the finest developments of yellowgray and mother-of-pearl colors, and juicy June with a colorful bouquet of wild flowers in an emerald vase, ripe strawberries and milk, with a Sunny landscape outside the window, half-open and calling us to run out to bask in the sun, and July with a bouquet of cornflowers and ears in a clay vase standing on the windowsill 
and written from the garden, as if inviting us to home; a little sad, and August with dried fish, beer and cigarette in the ashtray, golden grass and nascent thoughts about the end of the summer, and rainy November with a dry bouquet in a large vase, red cat, clay toys and a continuous flow of water on glass. and buoyant, joyful mood January with bullfinches and tits flying around in search of food, tangerine peels on the snowy table. All these works, imbued with a subtle lyricism and attraction to the infinite beauty of the world, are akin to the music of The Seasons by Antonio Vivaldi in terms of their impact on the viewer.

Philosophical orientation, subtle interpenetration of genres, pronounced lyricism, poetized perception and transmission of everyday objects of life, subtle color combinations, impressionism are the main features that are inherent in the masters of still-life of the Leningrad painting school in the second half of the 20th century.

\section{Poetry and light in the works of Olga Khorosheva}

Olga Khorosheva, a talented St Petersburg artist, is primarily attracted by the amazing accuracy, brevity of the image, bright and juicy color scheme, and absolute fidelity to the chosen themes.

The search for style, it seems, did not touch her creative manner at all. She chose her clear and fascinating pictorial language once and remains faithful to it for more than a dozen years. This makes her early works look surprisingly modern, and today's - timeless. This is largely due to the win-win in art themes and subjects chosen by the artist - women, children, flowers, nature. And in any portrait, female or child, in any story picture, in any still life or landscape - an amazing combination of vital truth and excited elation of the image.

Khorosheva's painting is active and emotional, it is recognizable by its juiciness, peculiar color and stylistic unity. Favorite shades of blue, blue, azure, turquoise fill the entire space of paintings depicting village children, teenagers and young women. Blue has many meanings and, supported by other colors-white, green, yellow-is perceived sonorously and at the same time sets off the other colors. A certain similarity of facial expressions of the characters, their large and always sad eyes, concentration, sharpness of the lines of the hands, a certain rigidity of movements cause persistent associations with the Fayum portrait, iconographic images and early parsuns (Dimochka, Nadyusha, 1992). In the of Pyatnashki (1993), children's images presented against the background of the circular forms of the earth and azure water merging with the sky, as if raised by the artist to the universal image of eternal youth. The works of Summer Batbing, By the Lake, Noon (2008) carry 
a shade of deep symbolism and evoke wonderful images of V.E. BorisovaMusatova. The beauty of the surrounding landscape, a young female body and modest wild flowers, as a symbol of modesty and chastity of the captured images are what the author tells us, clearly admiring his models.

Completely revived in spirit is the image of a teenager in the picture Dragonflies (1993). A boy kneeling in profile, movingly focused on dragonflies flying out of the palm of his hand, depicted against the background of a tall Bush resembling a Christmas tree and a huge piercing blue boundless lake, this image bears the stamp of the great Italian masters-Raphael, Botticelli, Carpaccio... The freshness of colors, clear composition, and generality of the landscape make the child's image majestic and sublime. The anatomical accuracy of the youth's body, his awkwardness, insecurity and exquisite elegance of hand drawing, the subtle reflexes of the skin, detachment from the noisy life near and focused on the seriousness of the gaze, or admiring whether studying the flight of dragonflies - all these makes the main character with images of teenagers in painting E. Moiseenko, who studied Olga Khorosheva. The interest in childhood and youth, so widely embodied in numerous portraits of Moiseenko, is perceived by the student in full and with high delight. Having absorbed from the teacher the psychology and immersion in the inner world of the characters, the light and complex world of the emerging personality, Khorosheva gives her paintings more picturesqueness, moving away from the classic moiseyenkov graphics, which makes her images more fragile and pathetic.

The canvas Boy on the Grass (1994), as well as Dragonflies, is filled with a deep generalized symbolic meaning. Touching naked fragile boyish figure lying on a white towel, the round shape of the hill, written in large, generalized strokes, fluttering butterflies, corners of the bright blue sky - everything is encrypted message of the author to the viewer, talking about the bright and clean world of the child, about his insecurity and at the same time about big dreams, read in a serious concentrated deep inside look.

Portraits of urban residents-children, women, and men-are always concise in composition and are remembered for their bright characters and rich color scheme.

The portrait of Nadenka (1990) admires above all with his masterly performance of red. The whole canvas is a hymn to the red, a hymn to the beauty of a talented girl. Scarlet, Burgundy, vermilion and delicate pink-all written in hot bright colors that emphasize the texture of fabrics and objects, mesmerizing, as in the canvases of Arkhipov, Petrov-Vodkin, Matisse and many others. The girl depicted with a book in her hands is beautiful. A deep intelligent look, a slightly timid girlish pose, an abundance of books on the table, a background of red 
Cannas - everything speaks of a great future for a talented person. Her soul is pure and tender, toys have not yet been forgotten, all the fairy tales have not yet been read, but her soulful, unchildlike eyes are focused on a beautiful bright future. Many years later, in the portrait of a teenage girl Anastasia (2009), the artist again turns to red, which models the form and emphasizes the elegance of the model.

Women's portraits occupy a significant and worthy place in the work of Khorosheva. In the paintings of Nani (1989), Svetlana (2003), Nadia (2005), the softness and plasticity of female figures are emphasized through the expressiveness of the drawing. They do not contain excessive detail and signs of time. They are quite concise and restrained in the color scheme. But each character feels the richness of the inner content and beauty of the soul.

Olga Khorosheva's landscapes are also imbued with an emotional sound. They fill the space of village portraits and holiday scenes, and they are represented by a separate independent genre. The artist masterfully conveys the quiet and unobtrusive beauty of the Central Russian landscape, relying on the best examples of Russian and Soviet landscape painting. The Silent Morning (1990) with its backstage construction of the composition, an exquisite range of greenish-blue tones, subtle in the foreground and generalized manner of writing in the background - despite the plot, has a strong emotional impact on the viewer.

Poetiziruet discreet landscape is characteristic of the works of the artist. In Golden Autumn (1989), the prevailing yellowish-ochre tones of birch crowns are combined with small patches of green shades of withering grass and white flashes on the trunks and water. Despite the General warm color scheme, the autumn landscape does not give us a major mood, it is full of quiet sadness, frozen on the withered dry bushes of once tender field grasses and flowers in the foreground, on the smooth stone jutting into the shore, and on the trunks reflected in the brownish water and from the color of this water seem devoid of crowns...

Artist Olga Khorosheva is recognizable. A strong painter, she went through a great school-graduated from the Academy of arts in the Studio of E.E. Moiseenko, an outstanding master and talented teacher. Of course, the capable student absorbed the main lessons of the teacher, but at the same time developed her own unique handwriting, whose name is bright picturesqueness, accuracy of drawing and a strong emotional beginning.

\section{Conclusion}

Kaleidoscope in the work of A.M. Lytkina 
The work of Alexander Mikhailovich Lytkin is very diverse and multi-faceted. Having received a classical art education at the Academy of Arts, constantly, daily developing their skills, making sketches and sketches, expressing their thoughts and ideas on paper Alexander Mikhailovich develops the classic experience of graphic artists and painters. Supporting and developing, he revealed his inner personal and individual characteristics in his work and was able to join the current interesting art of the time.

In his works there are a lot of thoughtful, perhaps rational, but at the same time very complex figurative elements, a lot of philosophical reflections, almost like a parable and aphorisms, clear images that are easy to read, laconically cut into the memory of the viewer (Russia is the Birthplace of Elephants, lithography). His works have several layers of ideas that complement and intertwine images and thoughts.

The master is constantly looking for creative, unusual in character and composition, unusual perspective and solutions of known subjects, expresses a new vision, a new interpretation of the images resulting in a series of paintings under the common theme of The Abduction of Europa (The Abduction of Europa, The Abduction of Europa 2, Abduction).

One of the characteristic features of his work is kaleidoscopic and fragmentary in images, compositional construction and plastic construction of a picture. There can be fragmentary, solved by lines, spots or color solutions, clear laconic decorative spots, using a formal principle to express personal vision. And this method does not interfere with the integrity of the image, the solution, but only emphasizes the character of the picture, the mood of the plastic form, the state of the lyric hero or landscape. This fragmentary and kaleidoscopic nature is very interesting to solve.

The picture of realistic images dissolves and outgrows, and is reborn, enriching the image, complementing the irrational and pointless spheres of the world. The combination of realism and abstraction complicates the author's works.

Kaleidoscopicity can be traced in such works of A.M. Lytkin as Kazan Cathedral, Windows, Fortune-Telling on Maps, Ice Drift, Leaf Fall, Autumn, Sphinx, Palmistry, Matera. St. Peter's Basilica, Magi, Blues, Morning at the Sink, Anger. The kaleidoscope system implies movement and development, which is also expressed in creative sheets.

\section{References:}

Andrey Mylnikov. (1977). Leningrad. 
Antonova, A. (1977). Still-Lifes of Viktor Teterin. Leningrad: Artists of Leningrad.

Art of the Soviet Union. Album. (1985). Leningrad: Aurora.

Exhibition of Works by 26 Leningrad and Moscow Artists. Catalog. (1990). Leningrad: Artist of the RSFSR.

Fine Art of Leningrad. Exhibition Catalog. (1976). Leningrad: Artist of the RSFSR. Interior and Still-Life. Exhibition of Paintings by Artists of the Russian Federation. Catalog. (1991). Leningrad: Artist of the RSFSR.

Ivanov, S.V. (2007). Unknown Social Realism. Leningrad School. St Petersburg: NPPrint.

Kekusheva-Novosadyuk, G.V. (1977). Evsei Moiseenko. Leningrad: Artist of the RSFSR.

Leonova, N.G. (1989). Evsei Moiseenko. Leningrad: Lenizdat.

Mochalov, L.V. (2000). Group of the Eleven. The Artist of Petersburg, 5. St Petersburg.

Mudrov, Y.V., Mudrova A.Y. (2014). Andrey Yakovlev. Album from the series of "Masters of Fine Art of the CIS Countries". Moscow.

Mudrova, A.Y. (2013). Creative "Odyssey" of Andrey Yakovlev. Petersburg Artist, 1(19). St Petersburg.

Mudrova, A.Y. (2012) The Cycle of Paintings by Andrey Yakovlev - Seasons of the Year. The International Artist Assembly Plastov's Autumn. September 24-27, 2012. Ulyanovsk.

Moiseenko, E.E. (2012). Collection from the Workshop. Album. St Petersburg: Historical Illustration.

Serebryanaya, V.I. (1987.) Yaroslav Igorevich Krestovsky. Leningrad: Artist of the RSFSR.

Smirnova, S.A. (2013). Y.I. Krestovsky. Still-Life and Landscape. St Petersburg: Wind Wose.

Tarasov, Y.A. (2004). Dutch still-life of the 18th century. St Petersburg: Publishing House of St Petersburg State University.

Verizhnikova, T.F. (2014). Small Dutch. St Petersburg: Aurora.

Vipper, B.R. (2015). The problem and development of still-life. 2nd ed. St Petersburg: Azbuka-Classic.

Shamanov, B.I. (1986). Catalog of the exbibition of works. Leningrad.

Volkogonov, S.A. (1971). Boris Ivanovich Shamanov. Leningrad.

Danilova, A.V. (2011). Still-life and picture of B.I. Shamanov in the context of the Leningrad School of Painting of the 1960s-1980s. Society. Development (Terra Humana), 3, 150-154. Leningrad. 
Dmitrenko, A. (1967) About time, about man. Smena, 3. November 11, Leningrad.

Evsei Moiseenko. (1975). Masters of Soviet Painting. Leningrad.

Ivanov, S.V. (2011). Twenty years later. Reflections on the exhibition of Sergei Osipov. The St Petersburg Art history Notebook, 21, 25-31. St Petersburg.

Ivanov, S.V. (2012). Quiet life at the Leningrad table. The St Petersburg Art History Notebook, 23, 90-97. St Petersburg.

Lipatov, V. (1984). Servant of Beauty. Culture and Life, 9, 16. Leningrad.

Moldavsky, D. (1966). Still-Life with an Axe. Leningradskaya Pravda, June 24, 4.

Nachev, D.A. (2014). Interpenetration of still-life and landscape on the example of creativity of Leningrad artists. Art and Dialogue of Cultures: 7th International Scientific and Practical Conference, 8: Collection of Scientific Papers, 231-234. St Petersburg: Herzen State University Publishing House.

Nachev, D.A. (2105). Stages of formation of the Leningrad School of Painting and the role of the still-life genre in this process. Art and Dialogue of Cultures: 9th International Inter-University Scientific and Practical Conference, 8: Collection of Scientific Papers, 105-107. St Petersburg: Herzen State University Publishing House.

Pushkarev, V.A. (1976). Fine art of Leningrad. Catalogue of the exbibition. Leningrad: Artist of RSFSR.

Still-Life. Exhibition of paintings by artists of the Russian Federation. (1973). Moscow.

Selizarova, E. (1962). Red and blue on orange. Leningradskaya Pravda, February 4, 2. Leningrad.

Selizarova, E. (1962). Claims to innovation. Leningradskaya Pravda, June 29, 3. Leningrad.

Smirnov, G., Solovyov A. (1962). Beginning Artist. Leningrad: Artist of the RSFSR.

Vanslov, V.V. (1975). Fine Art and Problems of Aesthetics. Leningrad: Artist of RSFSR.

Yaroslav Krestovsky (1983). Exbibition of works. Catalog. Leningrad.

Zaitsev, A.S. (1973). The advices of the master. Painting and drawing. Leningrad: Artist of the RSFSR.

Zimenko, V.M. (1971). Humanism of Art. Leningrad: Artist of RSFSR. 


\section{Appendix}

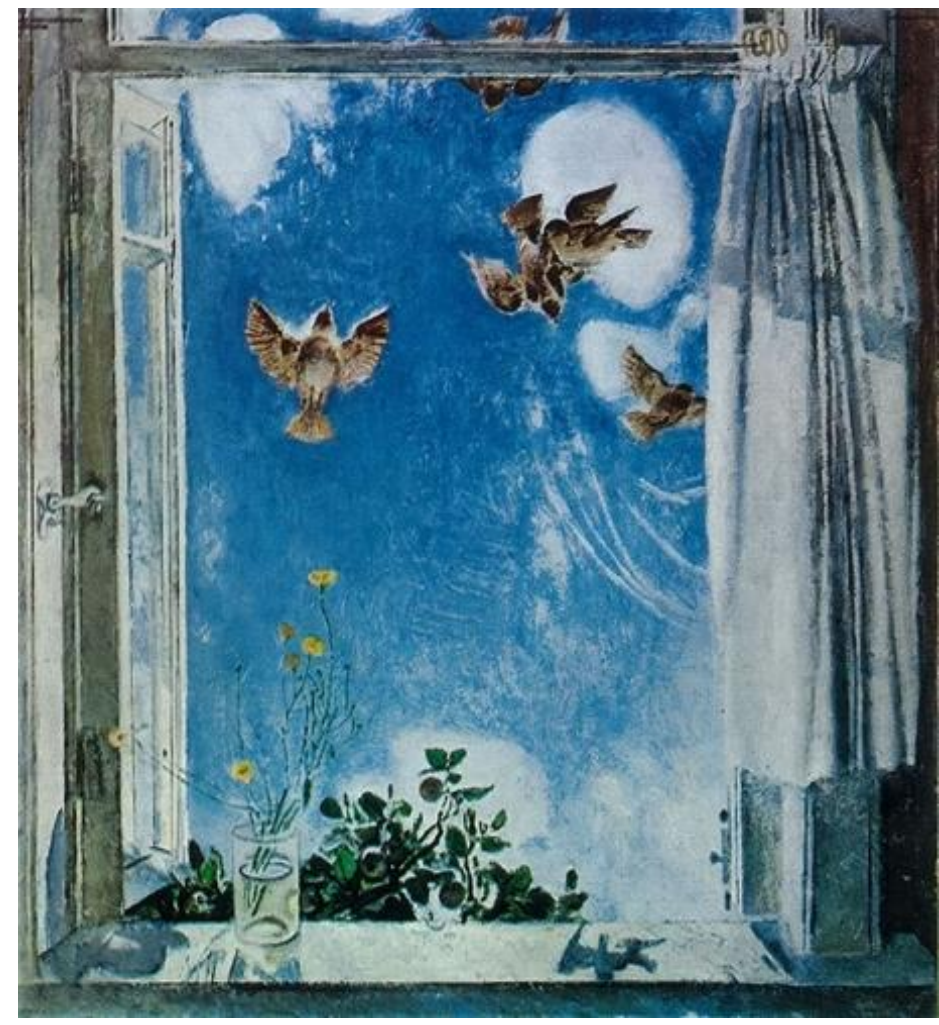

Fig. 1. E.E. Moiseenko. Blue Morning (1974)

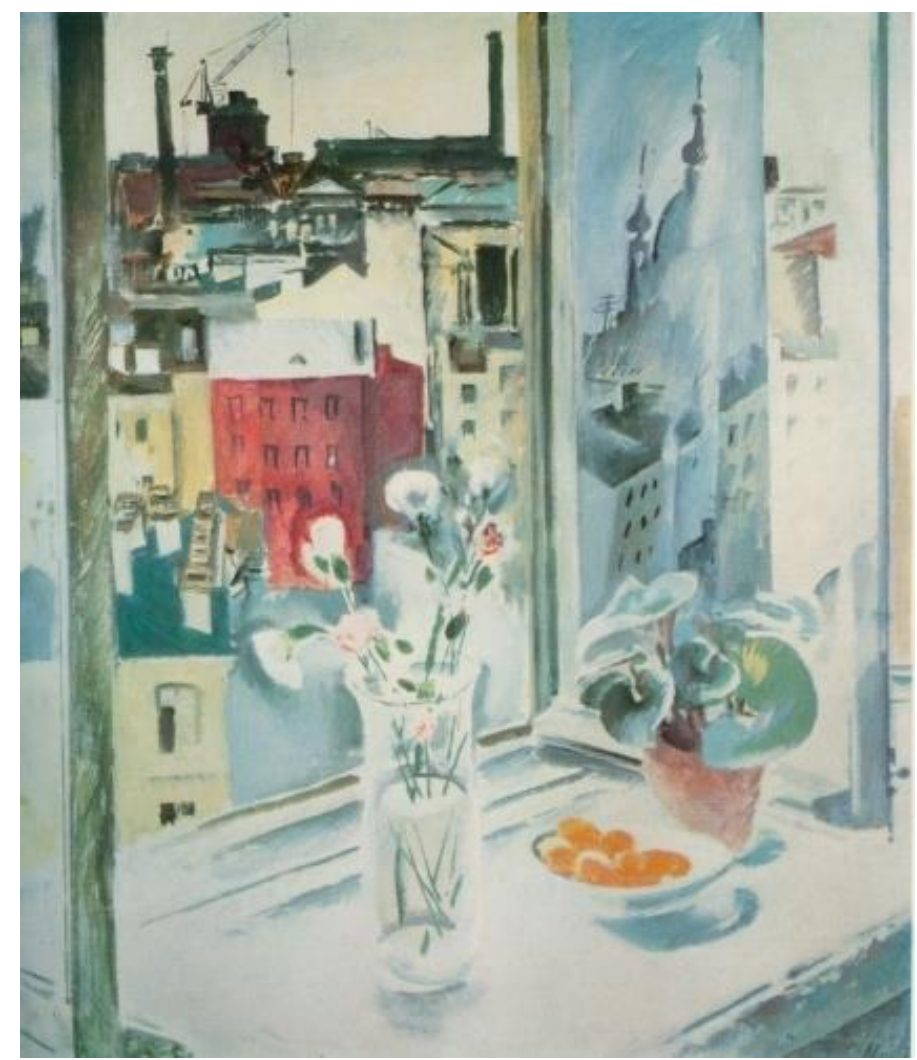

Fig. 3. E.E. Moiseenko. Window (1975)

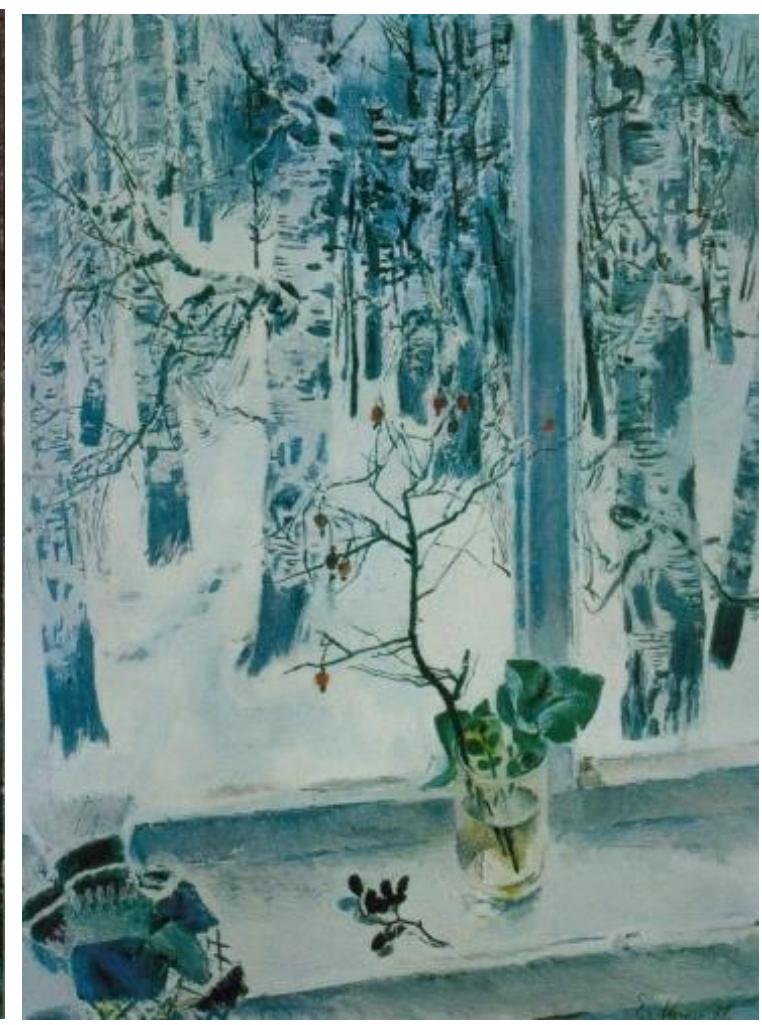

Fig. 2. E.E. Moiseenko. Winter (Birch) (1971)

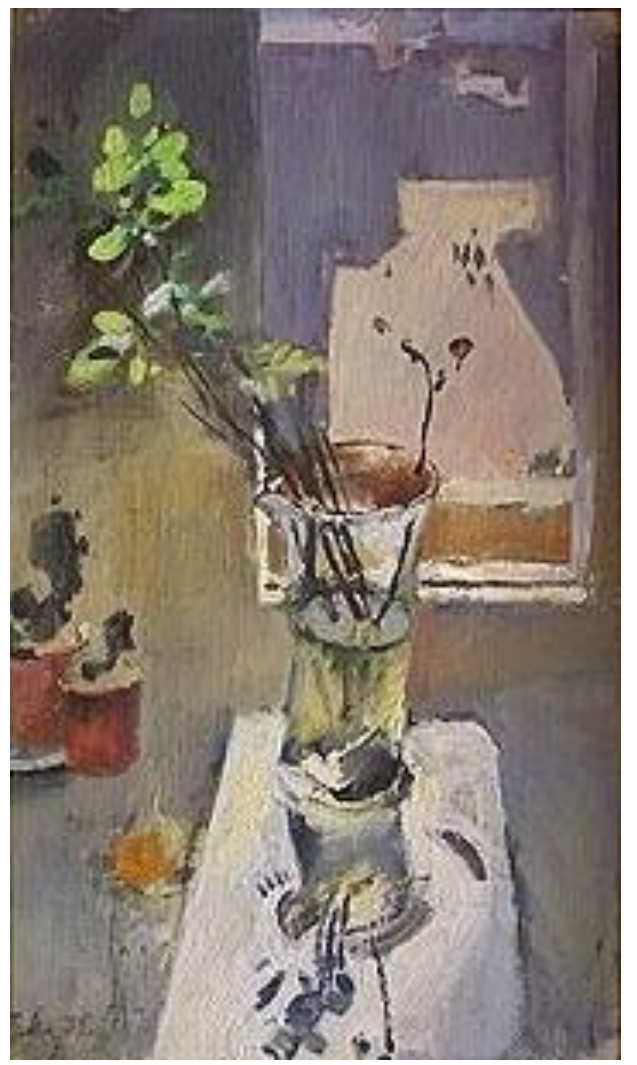

Fig. 4. E.E. Moiseenko. Still-Life on the Windowsill 

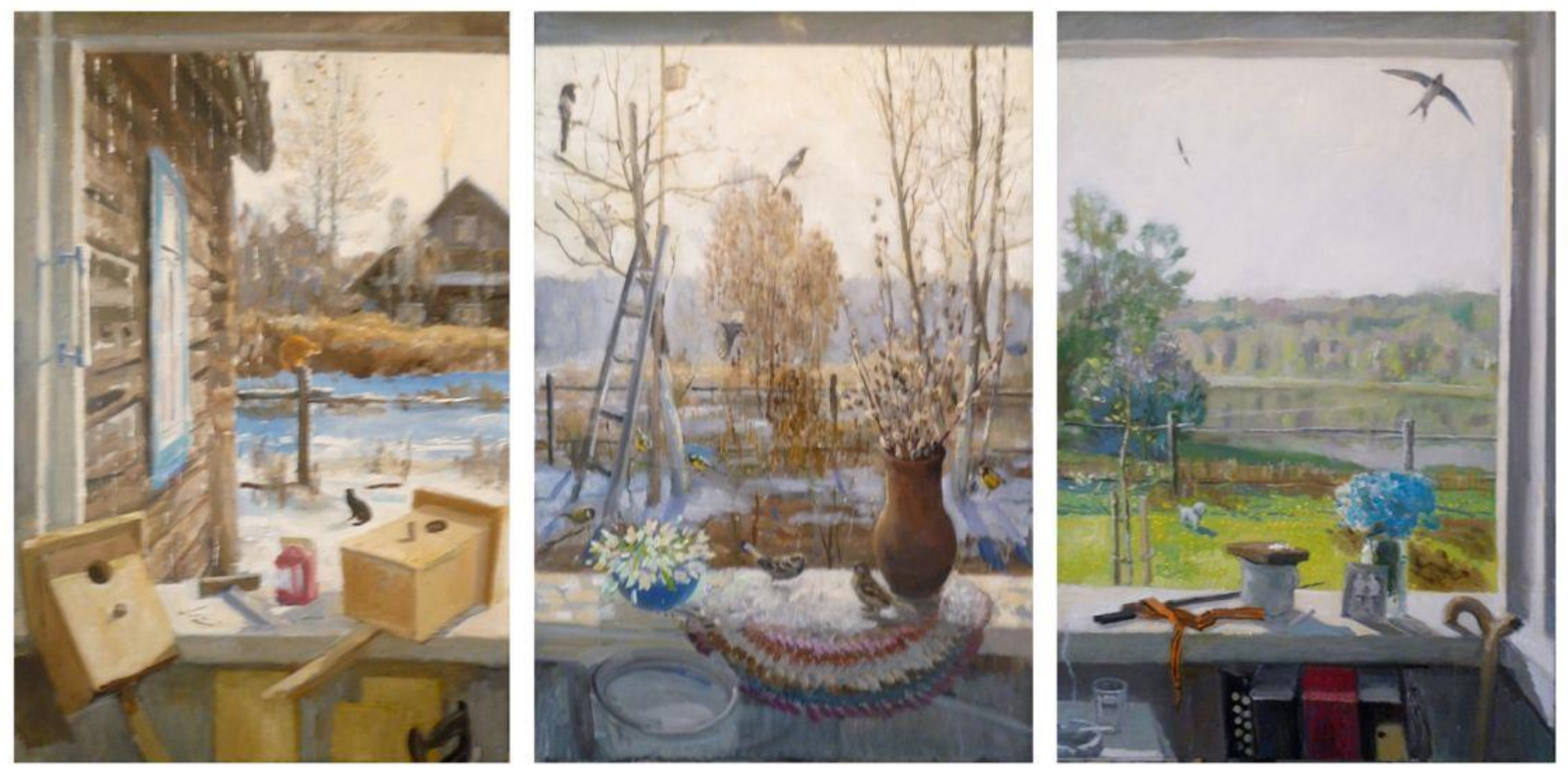

Fig. 5. A.A. Yakovlev. Spring (2011)
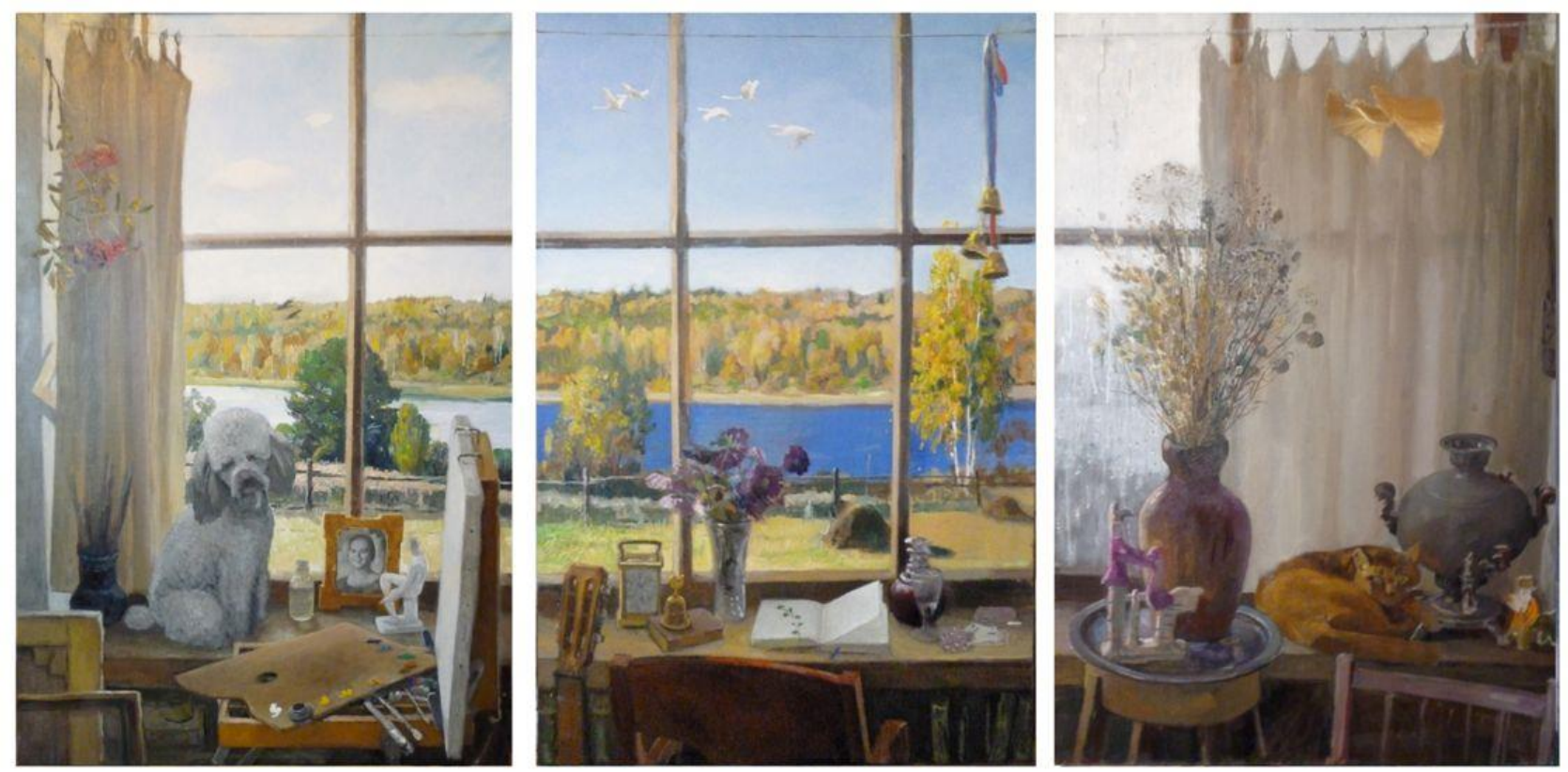

Fig. 6. A.A. Yakovlev. Autumn (2011) 


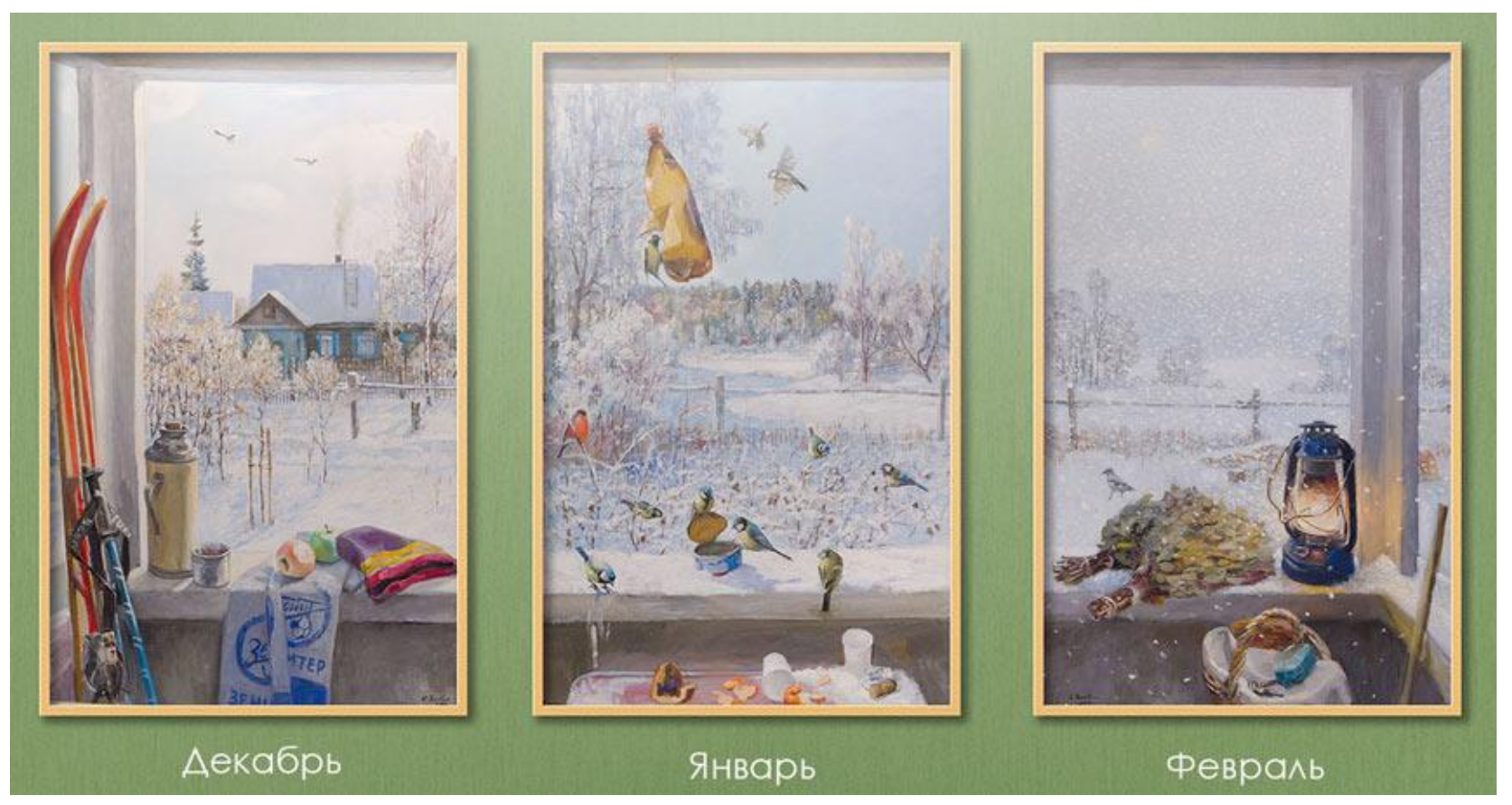

Fig. 7. A.A. Yakovlev. Winter (2011)

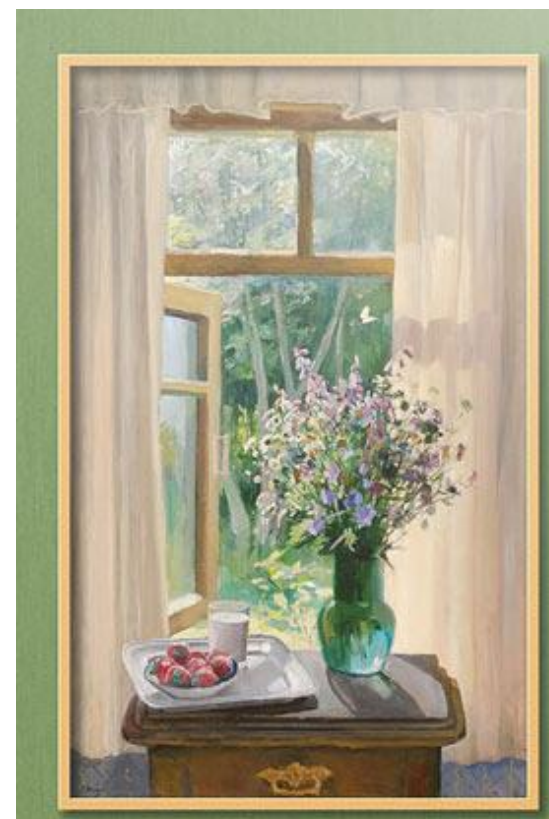

Июнь

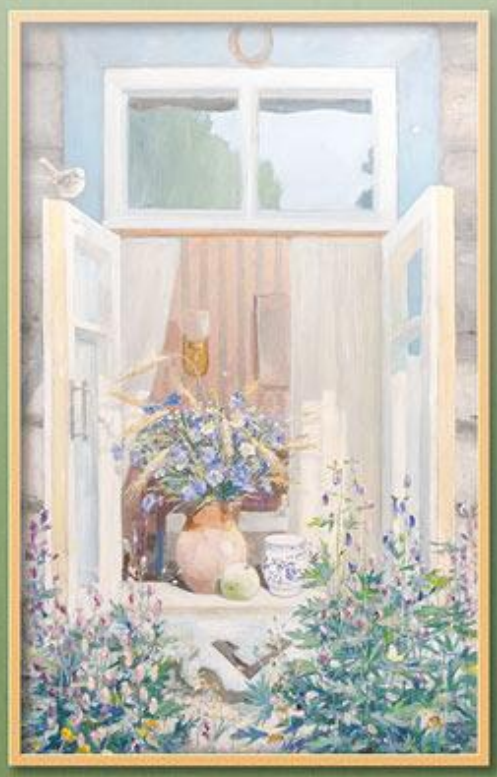

Ию^

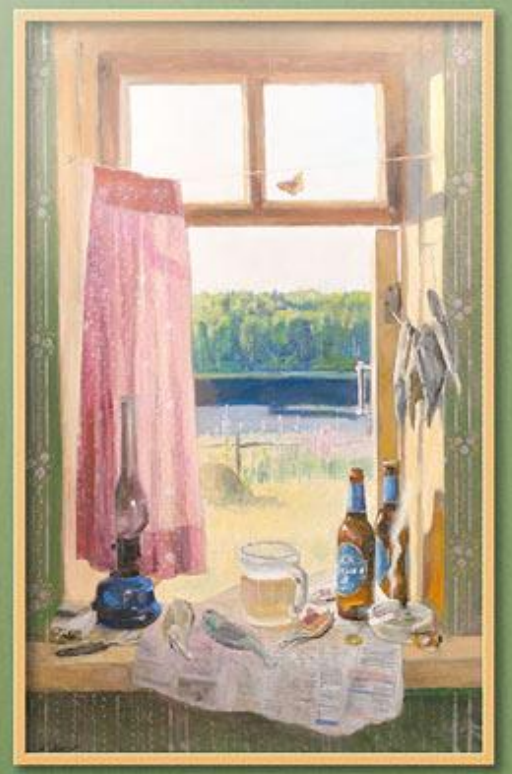

Август

Fig. 8. A.A. Yakovlev. Summer (2011) 


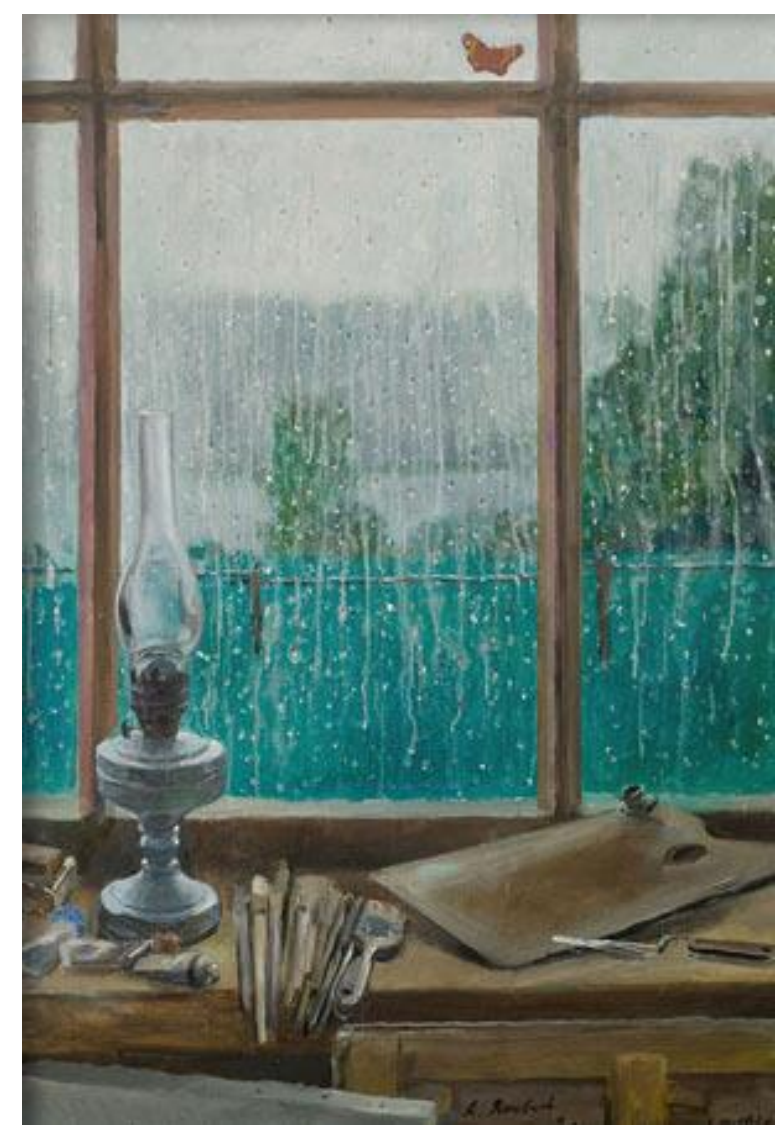

Fig. 9. A.A. Yakovlev. Bad Weather (2011)

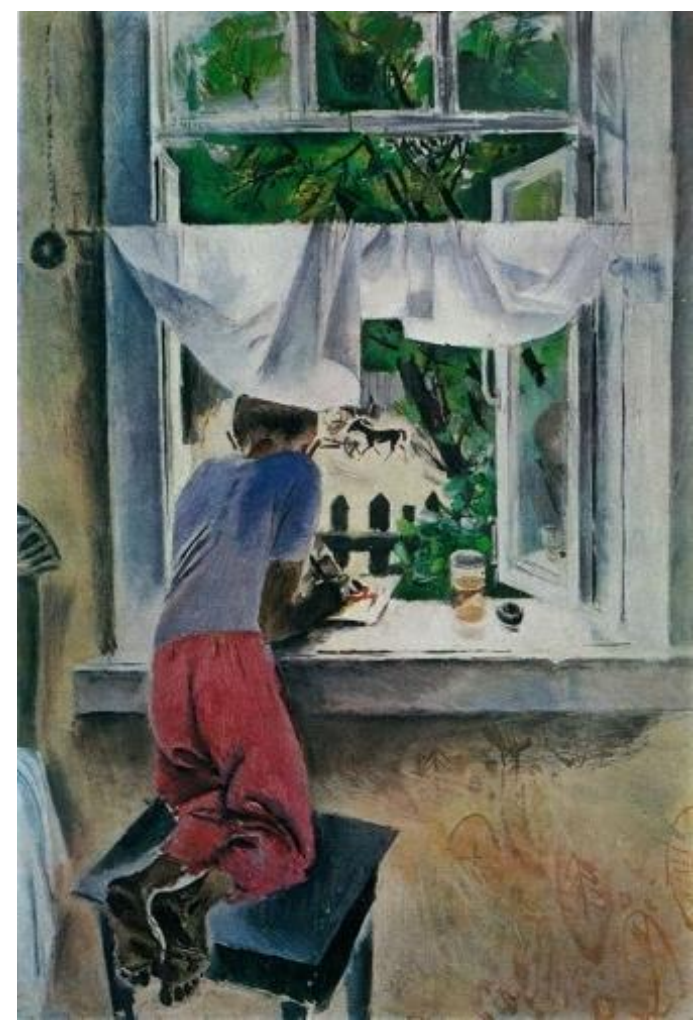

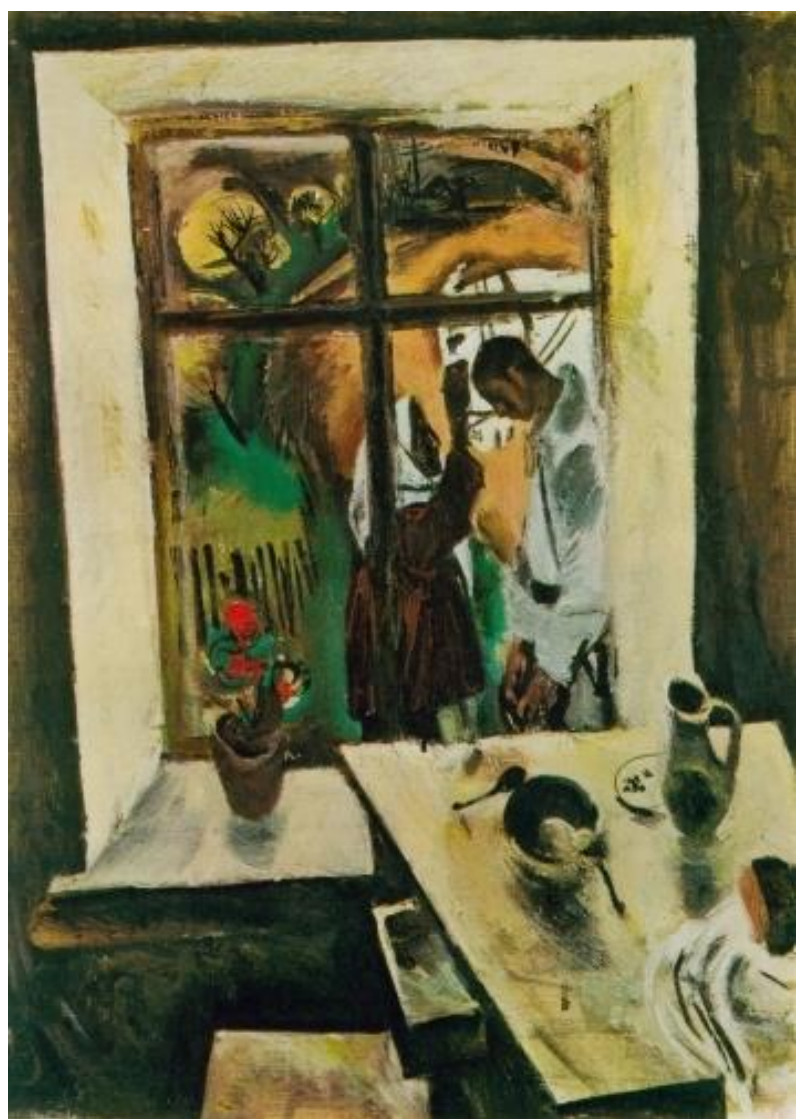

Fig. 10. E.E. Moiseenko. Son (1968)

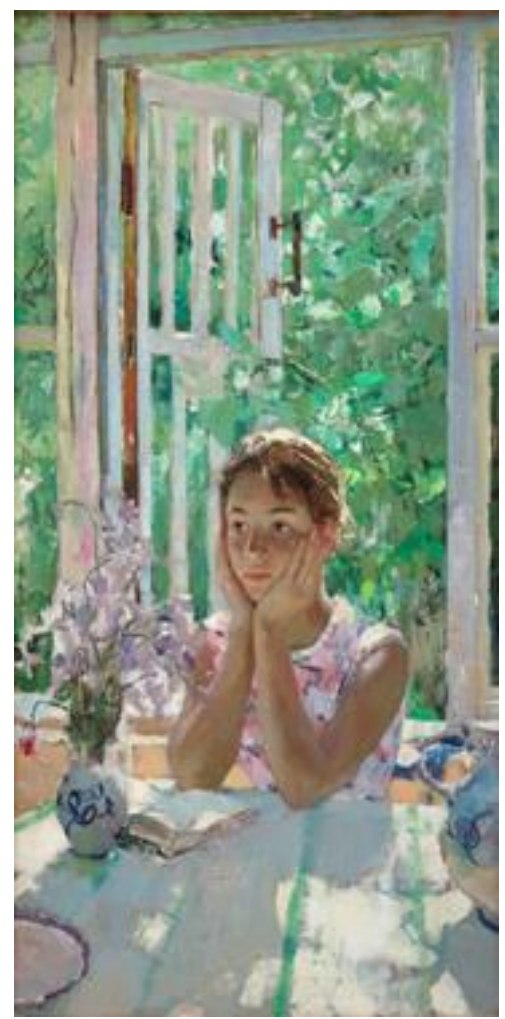


Fig. 11. E.E. Moiseenko. Young Artist (1970)
Fig. 12. A. Mylnikov. Vera on the Verandah (1964)

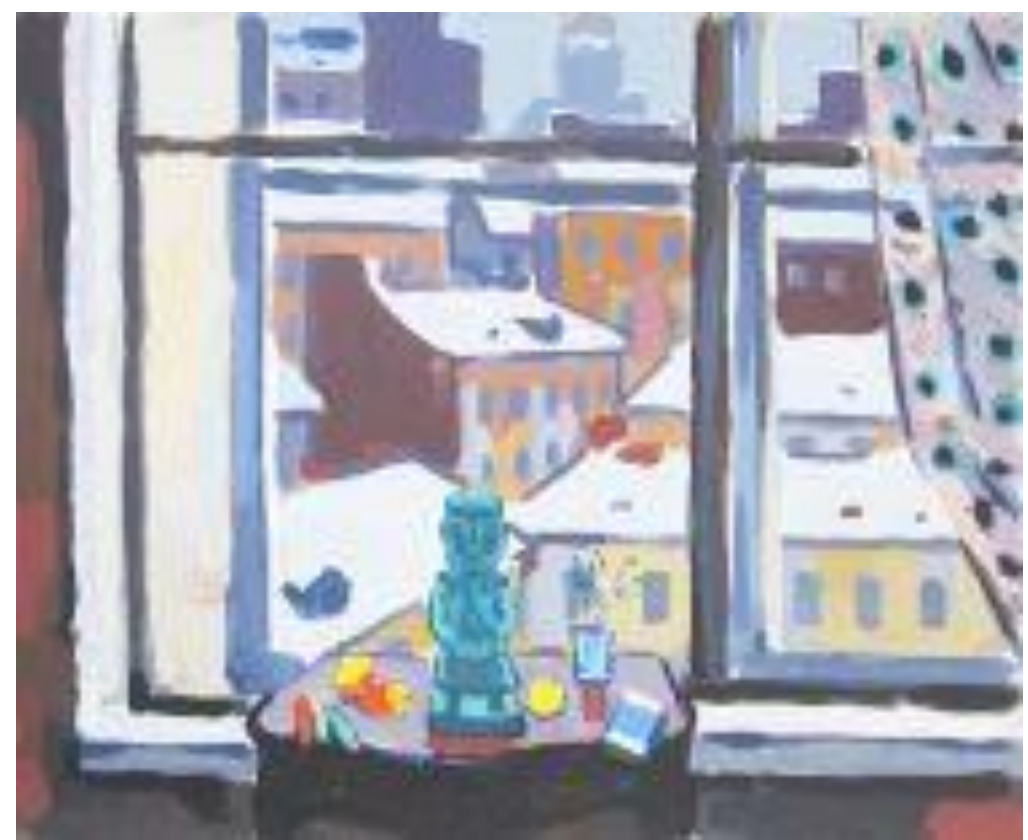

Fig. 13. Y. Krestovsky. Still-Life with a Chinese Figure and a View from the Window to the Roofs and Isaac Cathedral (1962)

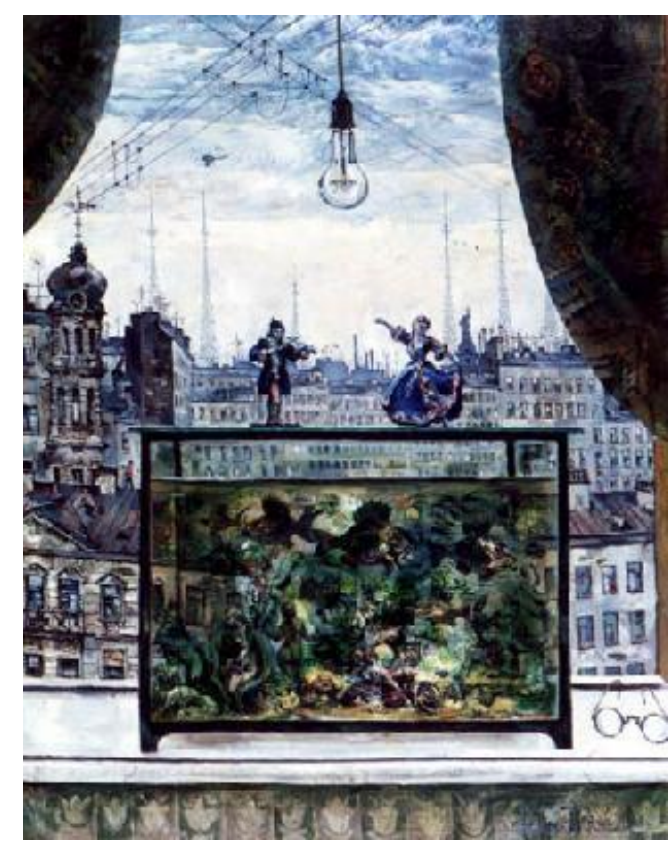

Fig. 14. Y. Krestovsky. Landscape with aquarium (1968)

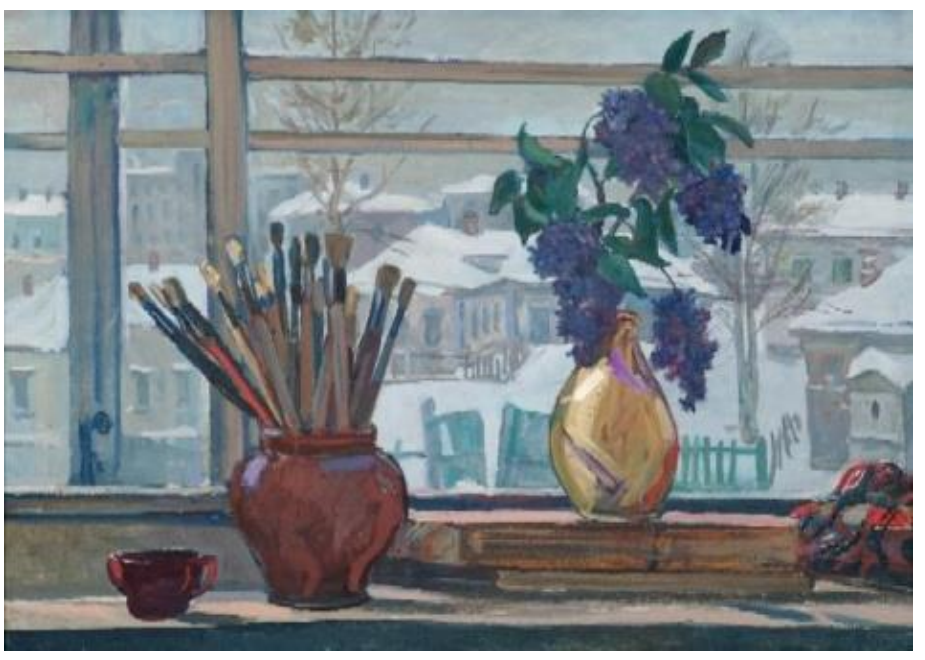

Fig. 15. A. Deineka. Window in the Studio (1947)

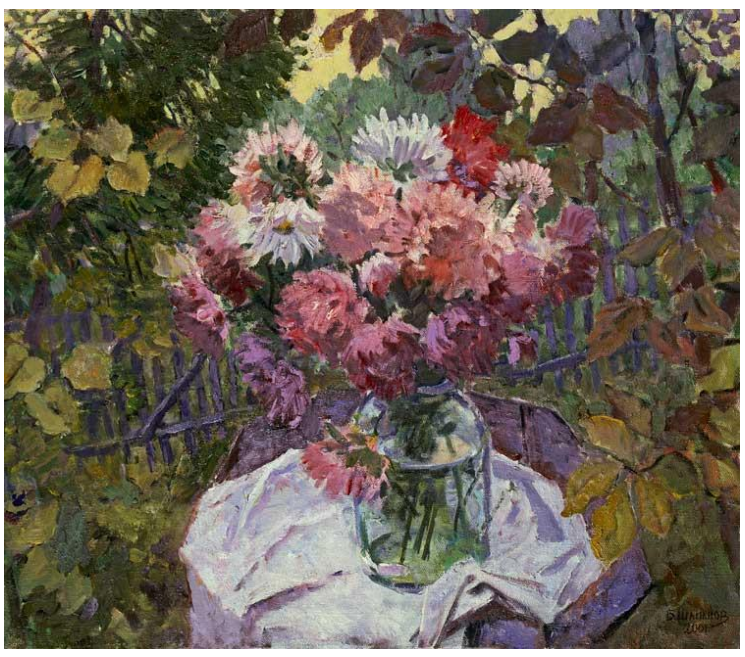

Fig. 16. B. Shamanov. Asters (2001) 


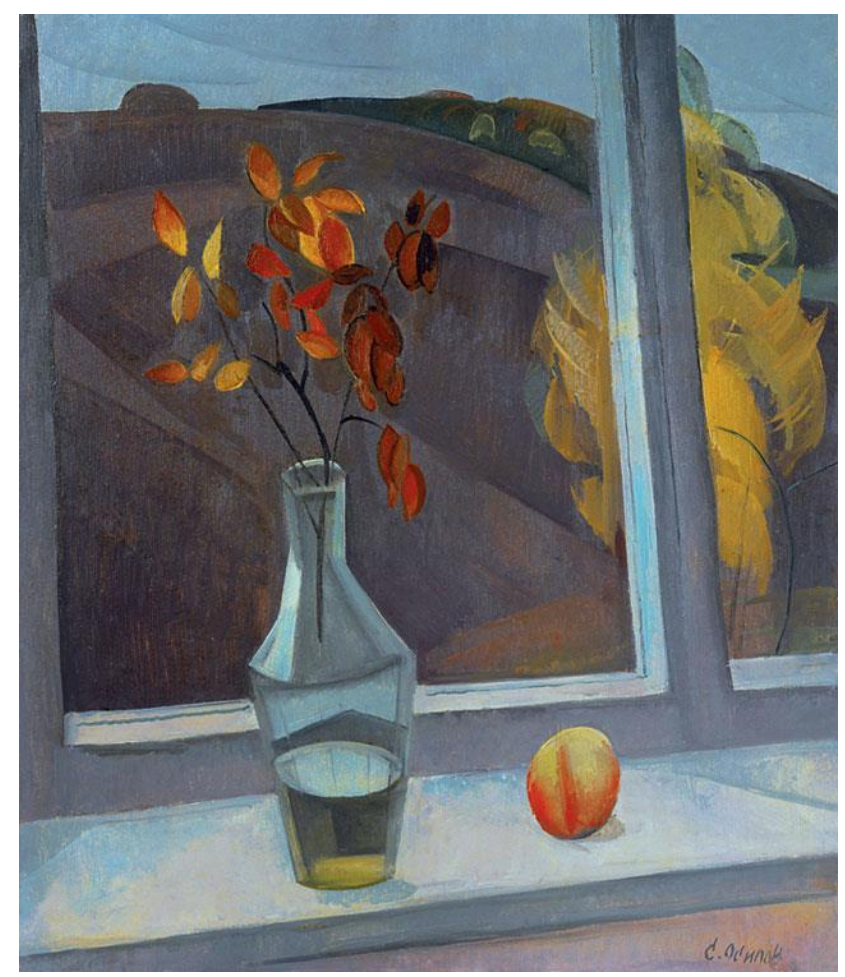

Fig. 17. S. Osipov. Autumn Branch (1974)

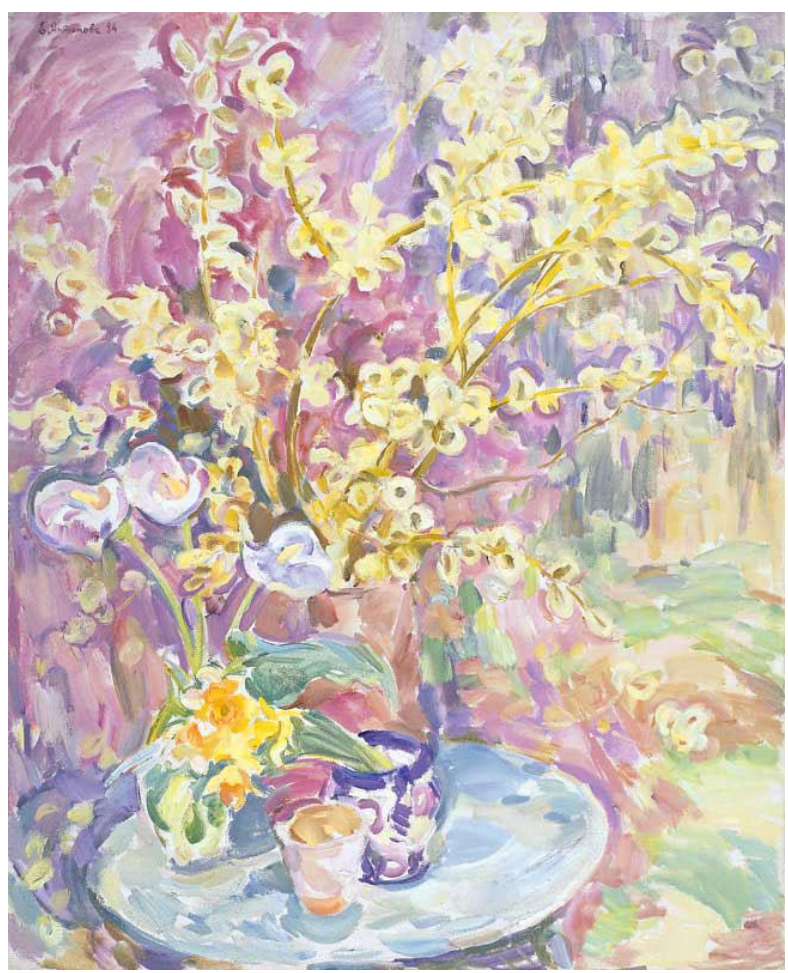

Fig. 18. E. Antipova. Blooming Willow, Calla Lilies, Daffodils (1984)

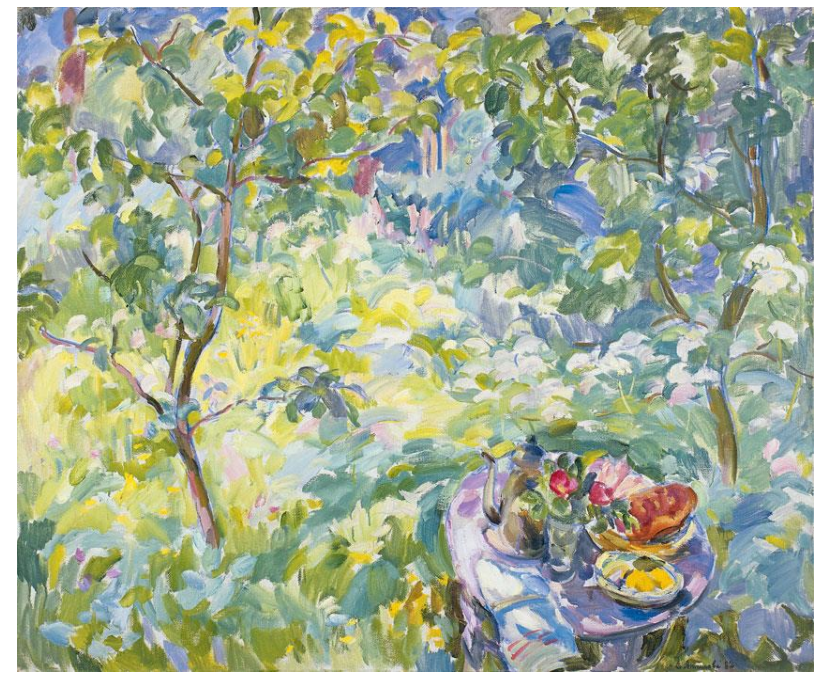

Fig. 19. E. Antipova. Midday (1982)

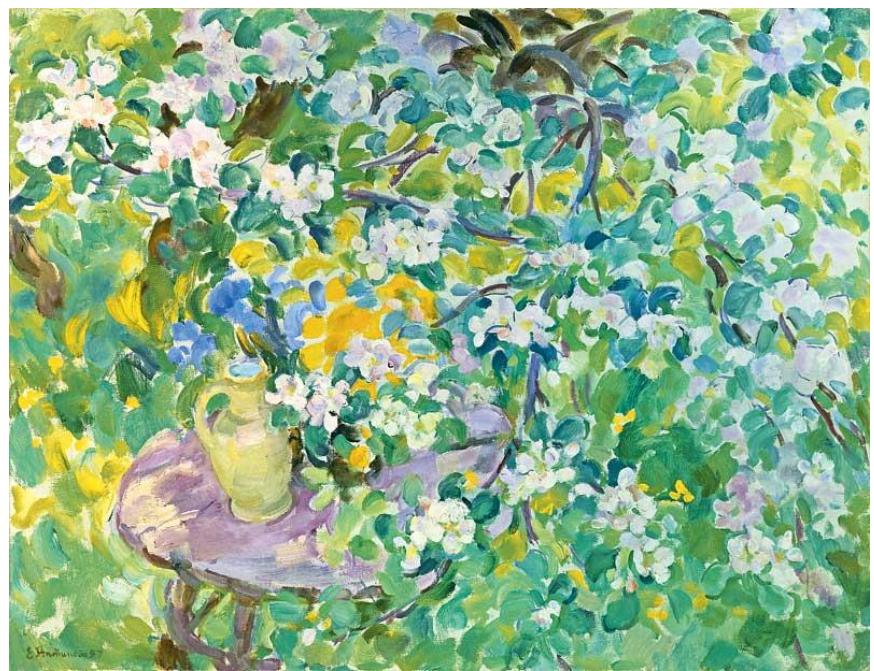

Fig. 20. E. Antipova. Apple tree in Bloom (1997) 


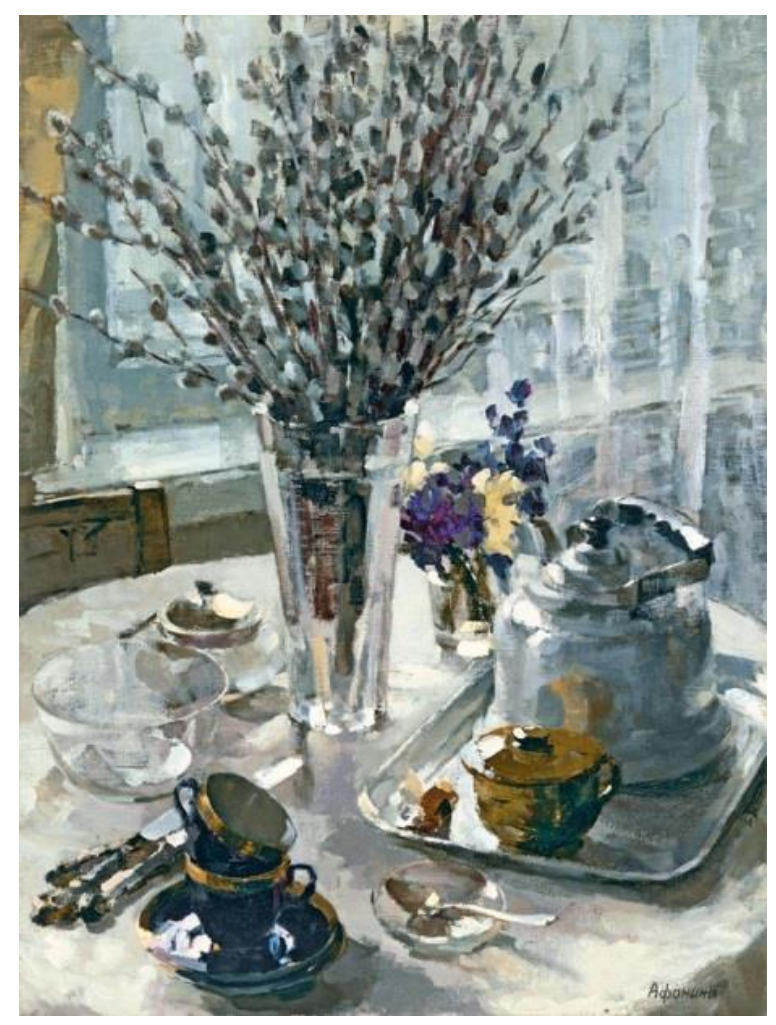

Fig. 21. T. Afonina. Still-Life with Willows (1964)

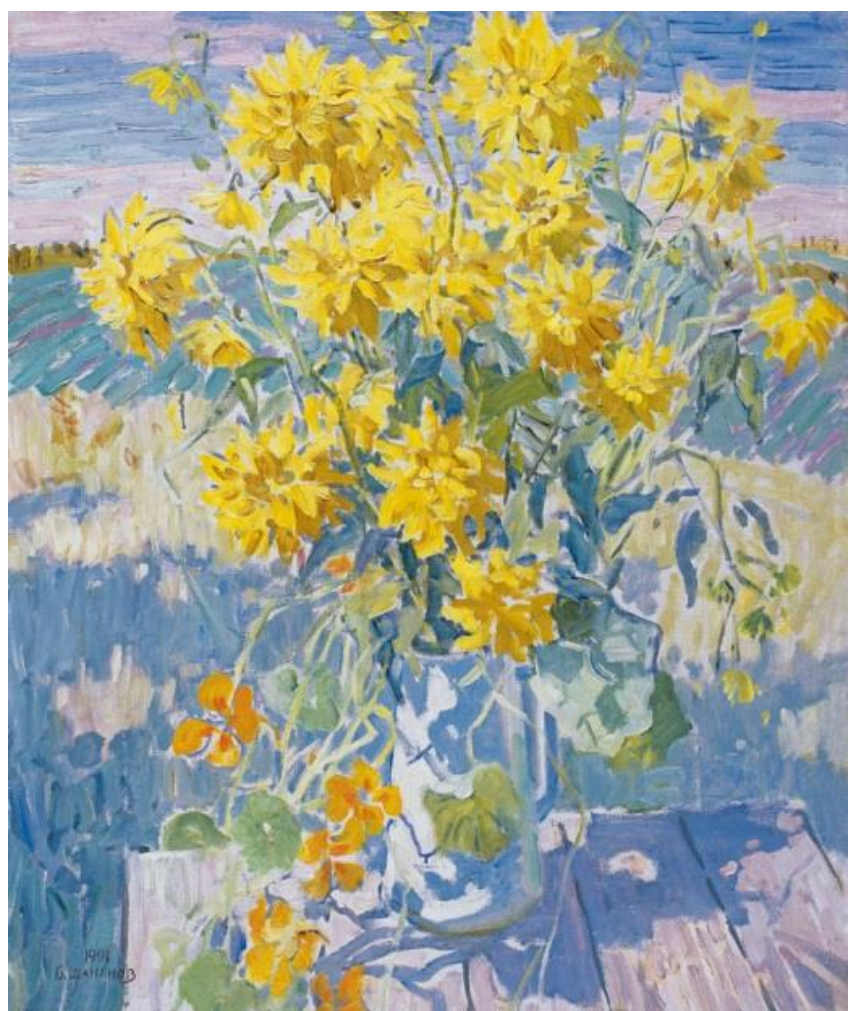

Fig. 22. B. Shamanov. September. Yellow Flowers (1991)

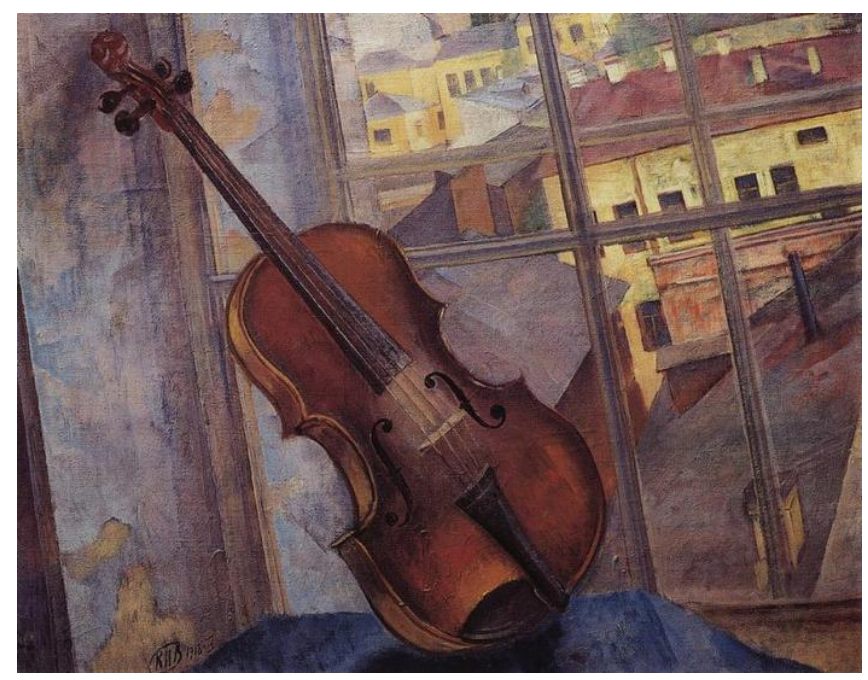

Fig. 23. K.S. Petrov-Vodkin. Violin (1918)

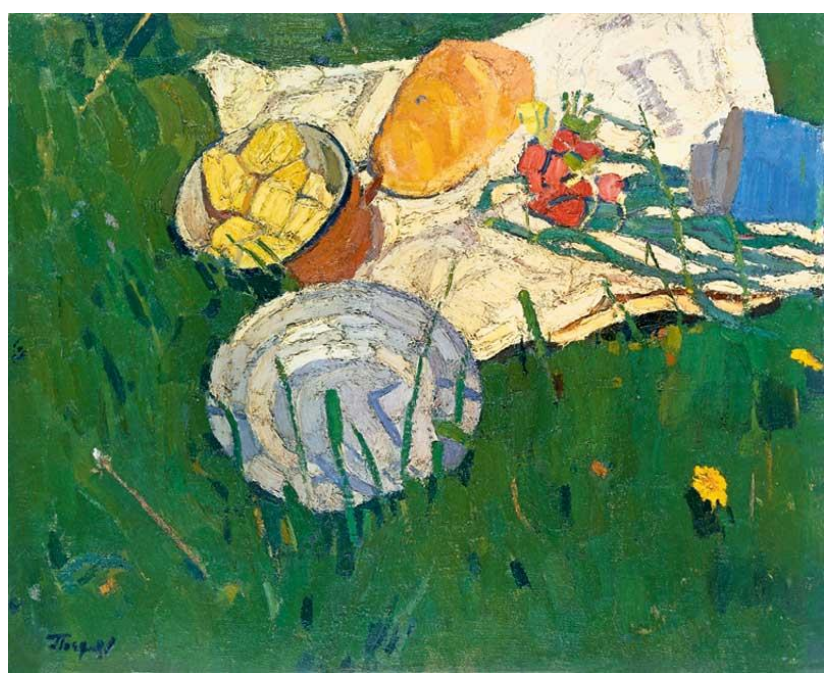

Fig. 24. N. Pozdneev. Still-Life in the Grass (1964) 


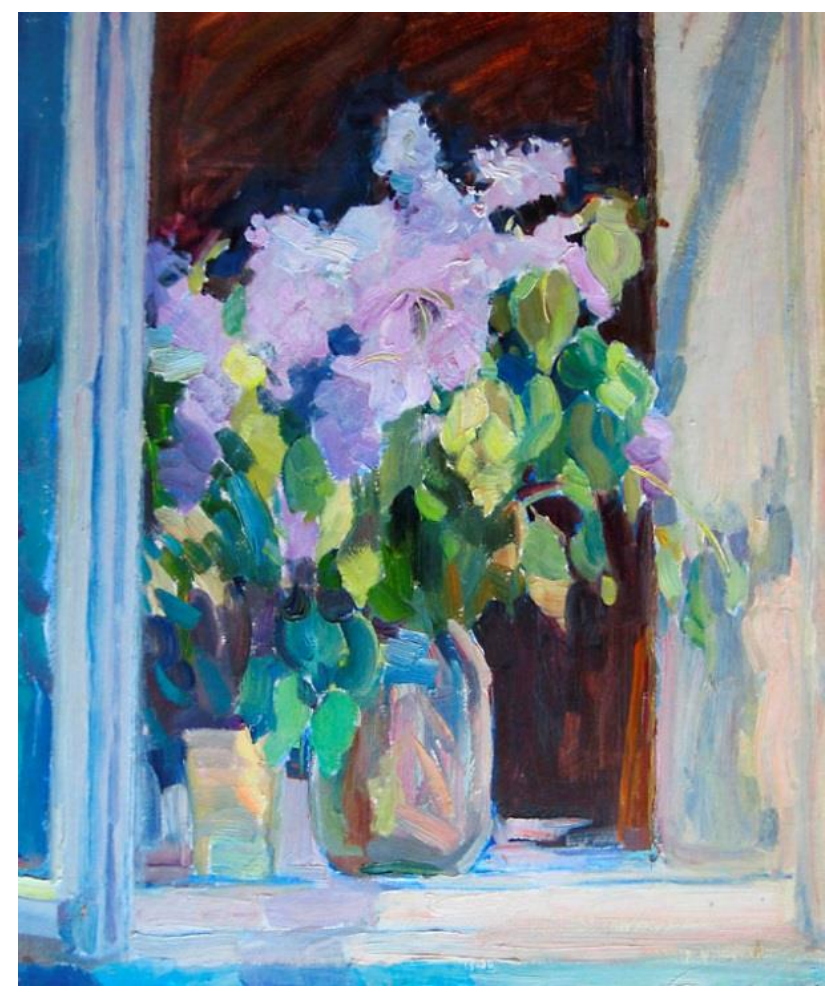

Fig. 25. A. Schmidt. Lilac in the Sun (1974)

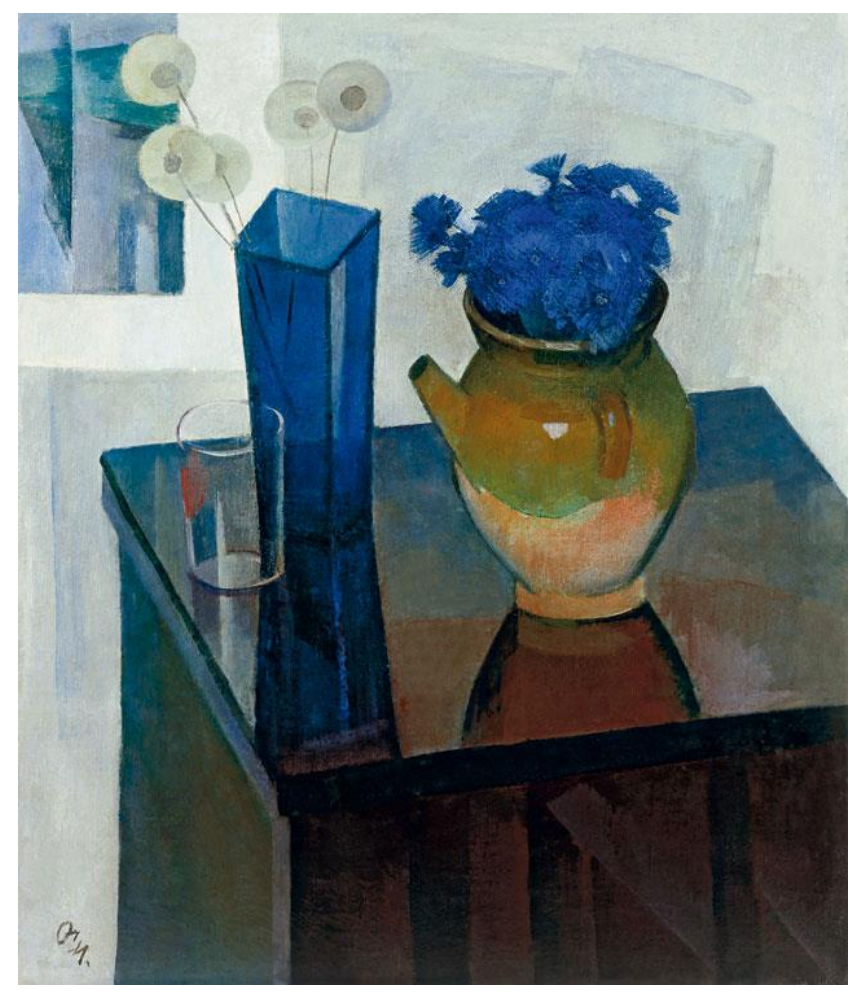

Fig. 26. S. Osipov. Cornflowers (1976)

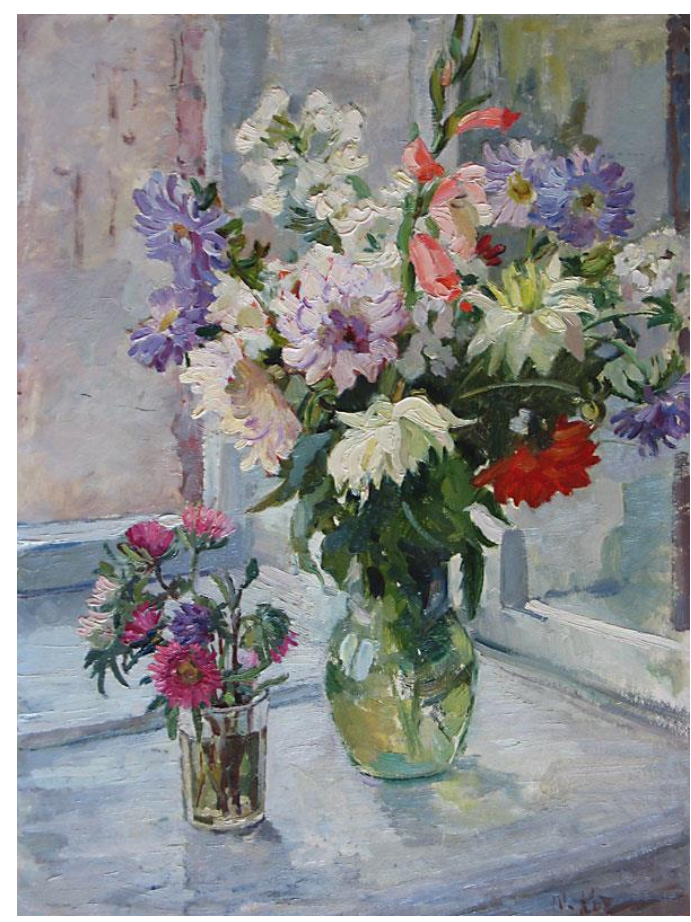

Fig. 27. T. Kopnina. Flowers on the Window (1957)

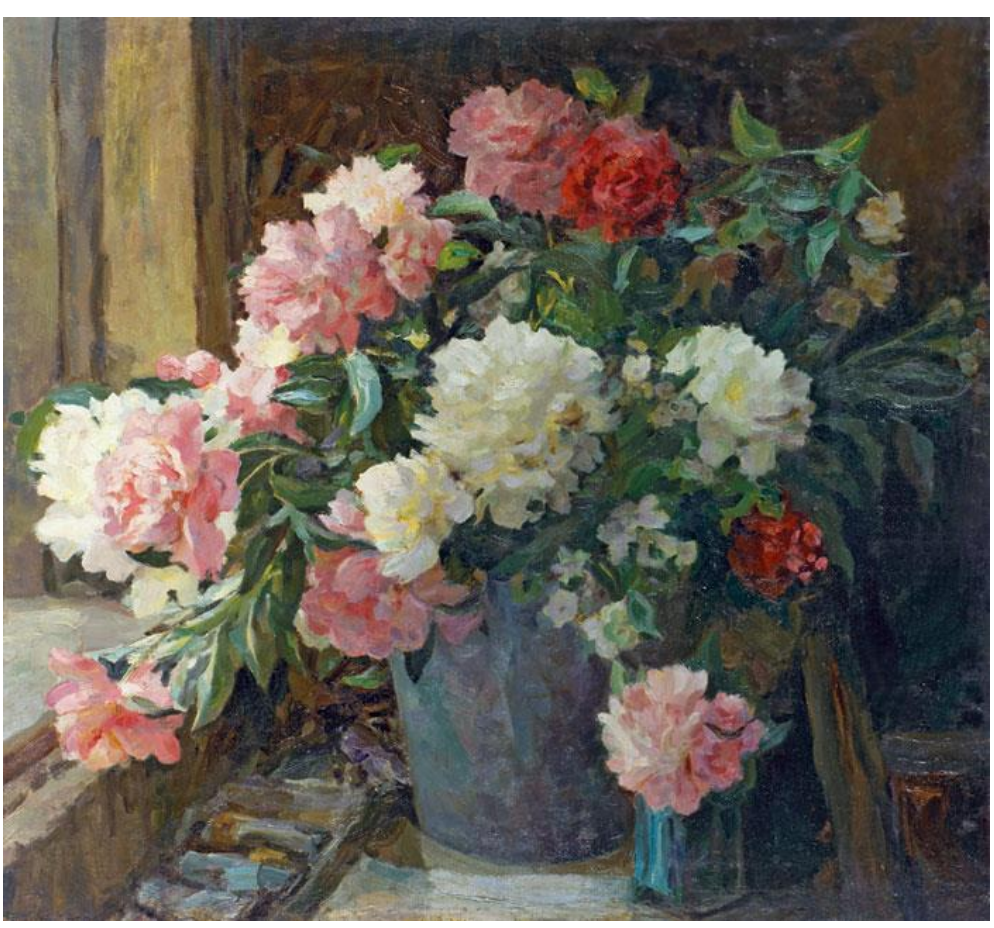

Fig. 28. E. Pozdnyakov. Peonies (1959) 


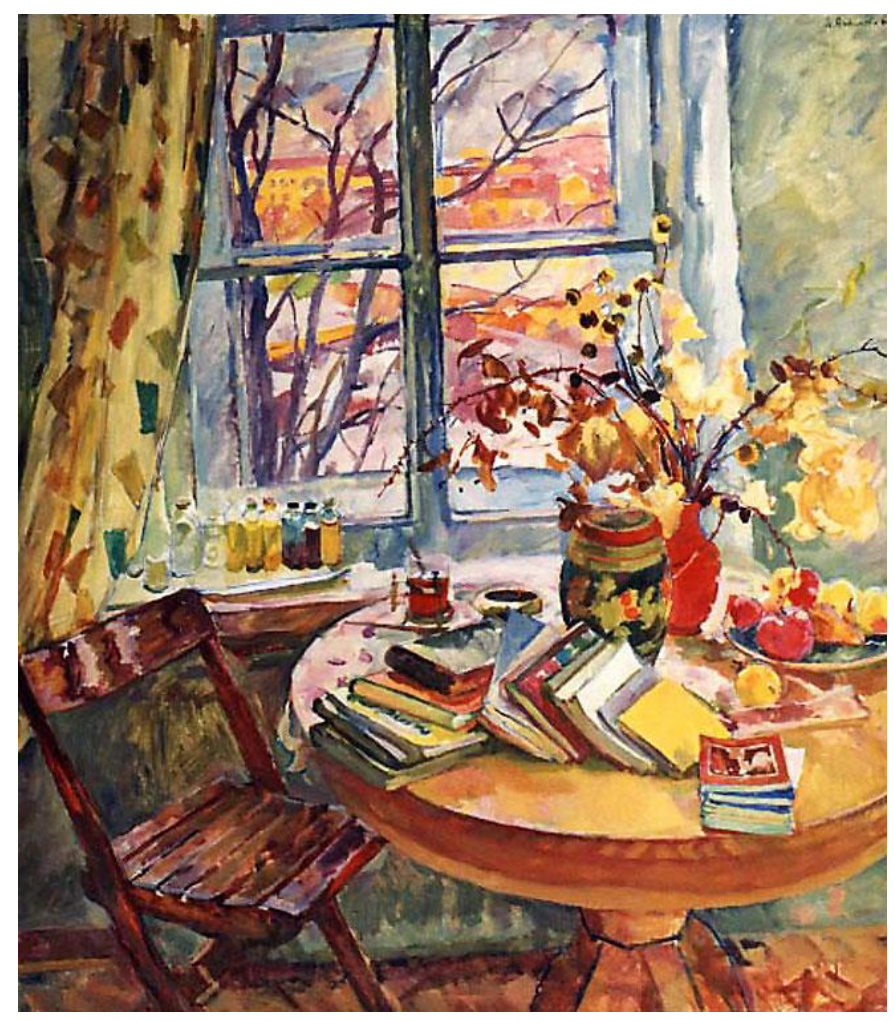

Fig. 29. E. Antipova. Books on the Table (1963)

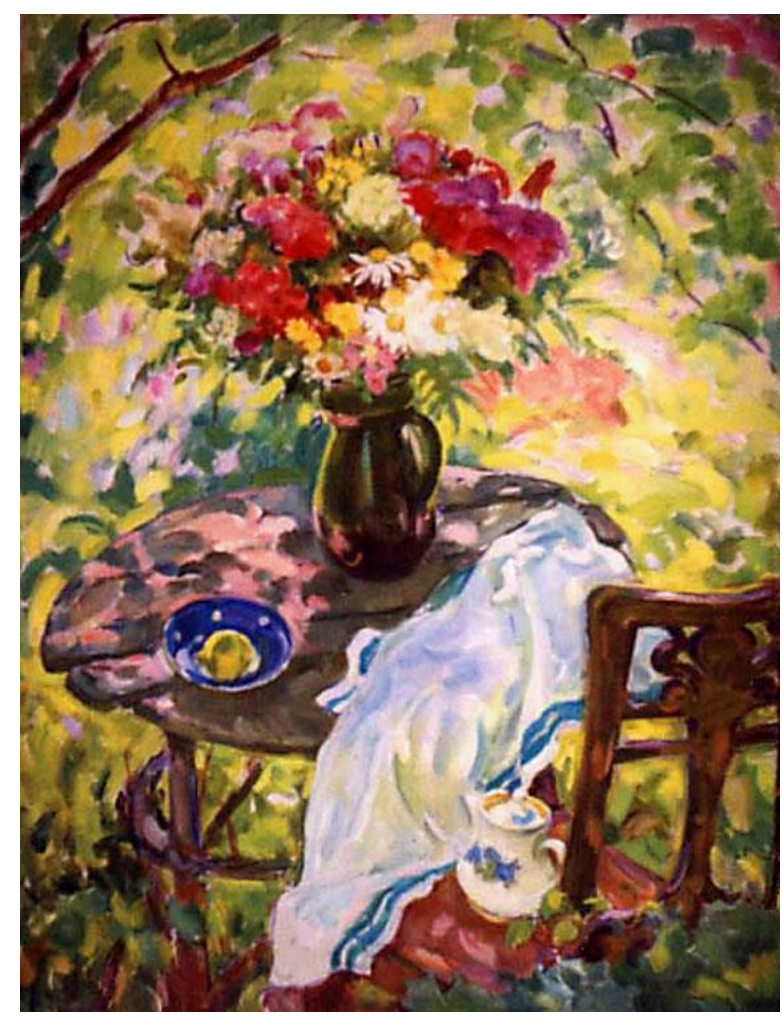

Fig. 30. E. Antipova. Still-Life in the Grass (1996)

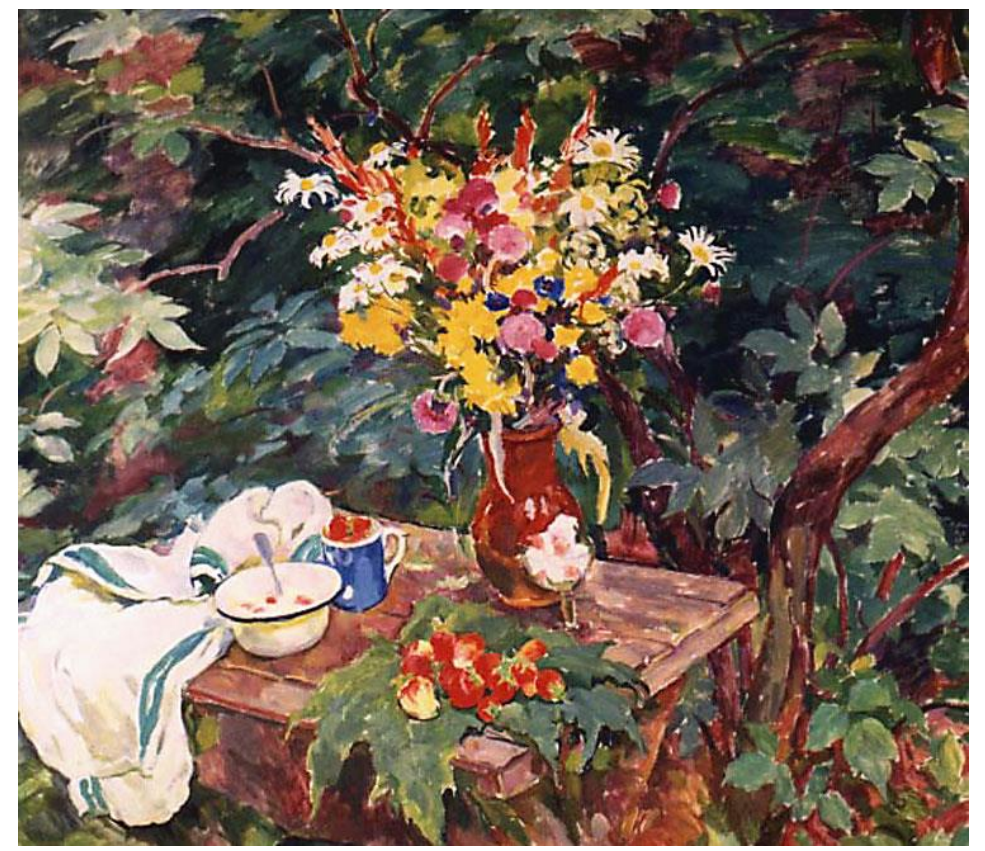

Fig. 31. E. Antipova. Still-Life with Strawberries (1960)

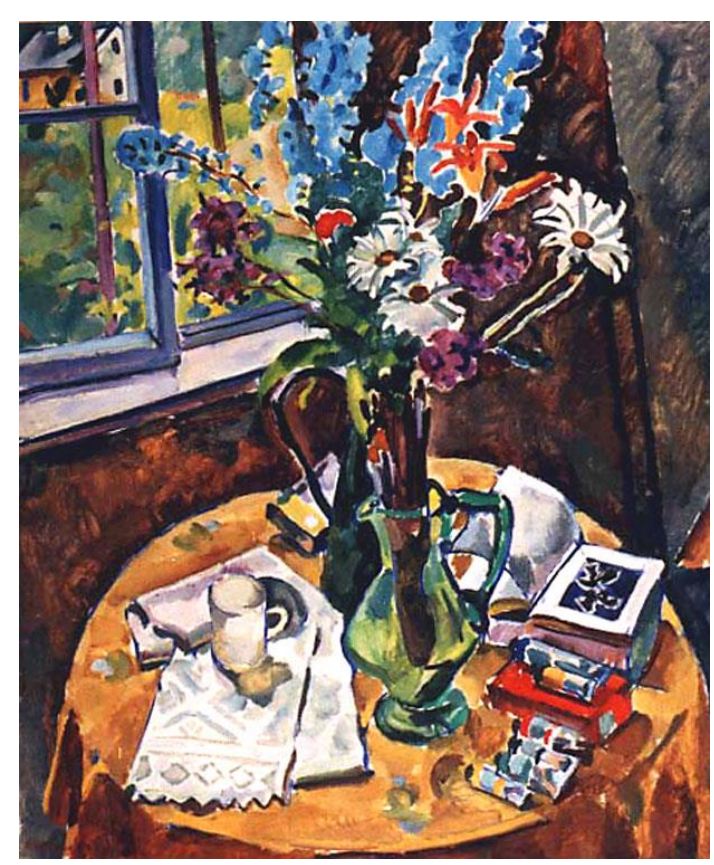

Fig. 32. V. Teterin. Still-Life with Flowers (1964) 
